\title{
Toward a Global Classification of Coastal Anthromes
}

\author{
Eli D. Lazarus
}

Environmental Dynamics Lab, Geography \& Environment Unit, University of Southampton, Highfield, Southampton, SO17 1BJ, UK; E.D.Lazarus@soton.ac.uk; Tel.: +44-02380-593-260

Academic Editors: Erle C. Ellis, Kees Klein Goldewijk, Navin Ramankutty and Laura Martin Received: 8 December 2016; Accepted: 2 February 2017; Published: 10 February 2017

\begin{abstract}
Given incontrovertible evidence that humans are the most powerful agents of environmental change on the planet, research has begun to acknowledge and integrate human presence and activity into updated descriptions of the world's biomes as "anthromes". Thus far, a classification system for anthromes is limited to the terrestrial biosphere. Here, I present a case for the consideration and validity of coastal anthromes. Every coastal environment on Earth is subject to direct and indirect human modification and disturbance. Despite the legacy, ubiquity, and pervasiveness of human interactions with coastal ecosystems, coastal anthromes still lack formal definition. Following the original argument and framework for terrestrial anthromes, I outline a set of coastal anthrome classifications that dovetail with terrestrial and marine counterparts. Recognising coastal environments as complex and increasingly vulnerable anthropogenic systems is a fundamental step toward understanding their modern dynamics—and, by extension, realising opportunities for and limits to their resilience.
\end{abstract}

Keywords: coastal development; fisheries; land-use change; social-ecological systems; coupled human-natural systems; anthropocene

\section{Introduction}

Human alteration of the world's coastal environments is both an old story and a new one: old, because the existence of human settlements along coastlines is nearly as old as the advent of human settlements themselves [1]; new, because human activities now dominate coastal and marine ecosystems around the planet, driving unprecedented rates of change in ecological habitats, community structures, and functions [2-7].

Archaeological remains suggest that early human ancestors included coastal marine resources in their diets [8,9] as early as 164 kya [10]. Migration routes reconstructed from mitochondrial DNA indicate that early humans migrated from East Africa east along the Indian Ocean coast into southeast Asia and Australasia $~ 65$ kya [11]. Evidence of seafaring peoples appears after $\sim 50 \mathrm{kya}$, and evidence of pelagic fishing —"advanced maritime adaptation", including fishhooks—after 42 kya $[12,13]$. New findings from western Canada suggest that the first human migration into the Americas 14 kya must have followed a coastal route, not the inland passage previously thought [14]. For the great majority of human history, the strongest external driver of change in ecosystem patterns was climate [15-17] —an early human coastal presence does not ipso facto equate to intensive environmental modification. Nevertheless, mounting evidence of coastal resource use among earliest humans is reorienting a persistent archaeological paradigm that our human ancestors had little interaction with coastal environments $[8,9]$.

If a biome is an ecological community characteristic of a given climate and geography, then an anthrome [18] is one that explicitly recognises biogeographies shaped by humans as "agents of biospheric change" [19]. Cognate research disciplines have recognised humans as agents of change in geomorphic [20] and Earth-scale systems [21,22]. All modern coastal environments are now subject to 
direct and indirect human modifications and disturbances [3-5,23] (Figure 1). Developed, exurban coastlines are effectively anthropogenic systems, with nutrient fluxes, sediment budgets, and habitats dictated by human activities [2-4,23-27]. Even in places under little pressure from coastal development, ecological legacies of intensive, often destructive, fishing practices mean that nearshore environments, shallow and deep, are not exempt $[7,28-30]$.
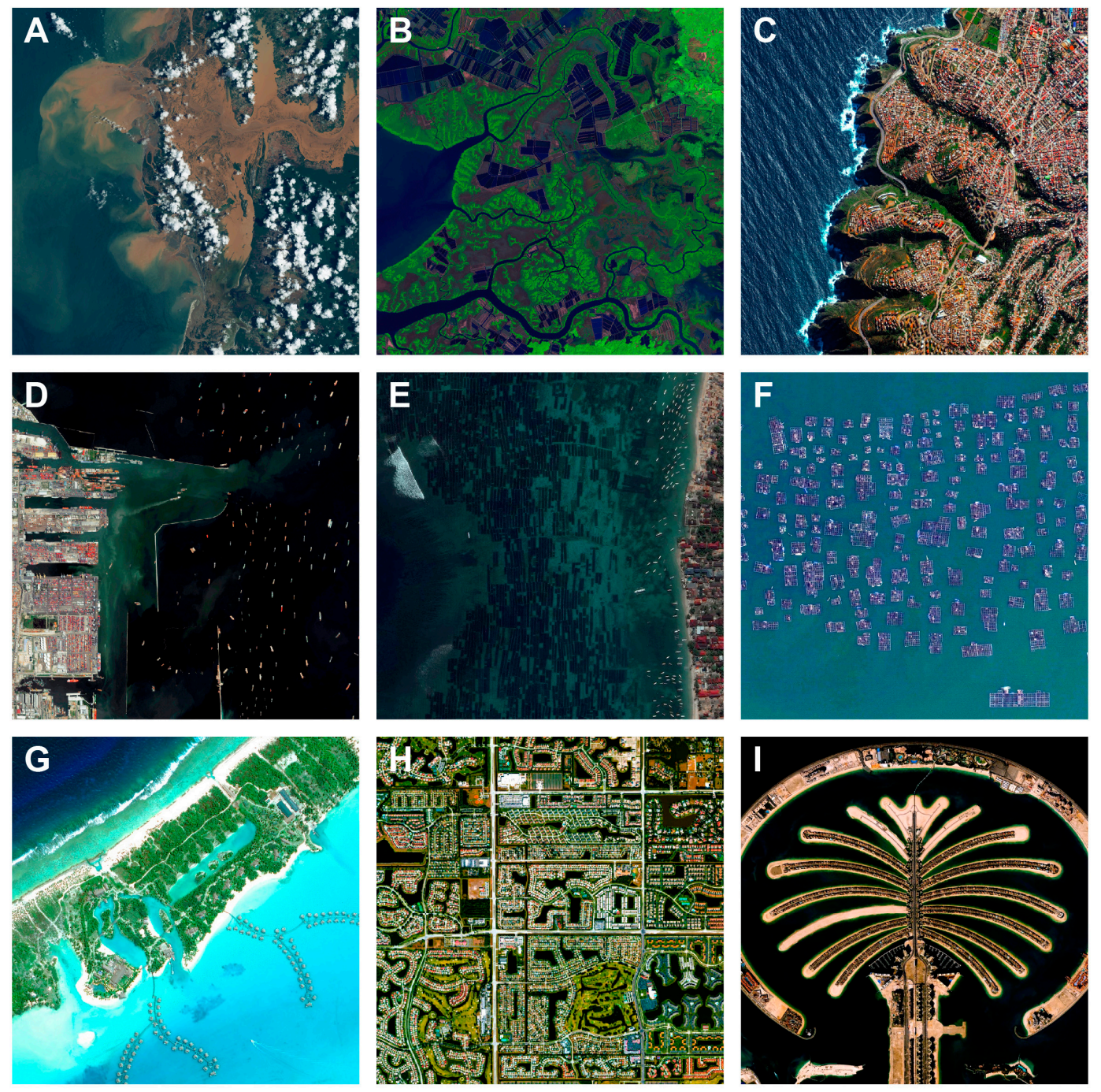

Figure 1. Examples of human-coastal environments, or aspects of potential coastal anthromes: (A) Suspended sediment at the mouth of the flooded Tsiribihina River, Madagascar $\left(19^{\circ} 42^{\prime} 01^{\prime \prime} \mathrm{S}\right.$, $\left.44^{\circ} 33^{\prime} 00^{\prime \prime} \mathrm{E}\right)$; (B) Mangroves converted to shrimp ponds on the west coast of Honduras (13 $04^{\circ} 04^{\prime \prime} \mathrm{N}$,

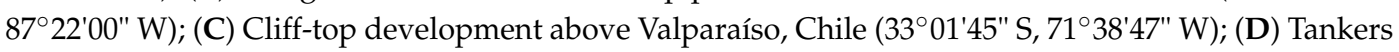
and port complex at Tanjung Priok, Jakarta, Indonesia (6 $06^{\prime} 14 "$ S, $106^{\circ} 53^{\prime} 11^{\prime \prime E)}$; (E) Seaweed farming at Nusa Lembongan, Indonesia $\left(08^{\circ} 41^{\prime} 50^{\prime \prime}\right.$ S, $115^{\circ} 26^{\prime} 40^{\prime \prime}$ E); (F) Fish farms in the Taiwan Strait $\left(24^{\circ} 48^{\prime} 40^{\prime \prime} \mathrm{N}\right.$, 119 55'42" E); (G) Resort on Motu Tehotu, French Polynesia (16 28'19" S, 151 ${ }^{\circ} 42^{\prime} 26^{\prime \prime}$ W); (H) Housing subdivisions and canals in Boca Raton, Florida, USA (26 $\left.22^{\prime} 07^{\prime \prime} \mathrm{N}, 80^{\circ} 06^{\prime} 00^{\prime \prime} \mathrm{W}\right)$; and (I) The Palm Jumeirah, a made-ground development in Dubai, UAE (2506' $\left.53^{\prime \prime} \mathrm{N}, 5^{\circ} 08^{\prime} 16^{\prime \prime} \mathrm{E}\right)$. (Images: (A,B) via NASA Earth Observatory; (C-I) via Daily Overview/DigitalGlobe.)

Despite such robust and diverse evidence of human-coastal interactions-and even system coevolution [31] — coastal anthromes still lack formal definition as environmental types. A systematic definition of the world's coastal anthromes would be a critical advance for efforts to understand and anticipate social-environmental system response to forces of change [5], particularly as issues 
arising in terrestrial and marine settings converge [26,32,33]. Here, I present a case for the validity of coastal anthromes. I also outline a set of steps toward a coastal anthrome classification that dovetails with existing terrestrial and marine counterparts, following the original theoretical argument and framework for terrestrial anthromes proposed by Ellis and Ramankutty [18]. Attempting to organise an anthrome classification scheme raises challenging questions that are interesting unto themselves [34], but those challenges also frame opportunities for scientific progress. The various examples of possible coastal anthrome classes discussed here are more illustrative or representative than comprehensive or definitive. However, as Halpern and Fujita [34] note in their synthesis of cumulative impact analysis for marine ecosystems, "one important advantage of having to identify and address data gaps is that the process of doing so provides a rational and comprehensive means for guiding policy and decision makers"—and other researchers-"towards gaps that are the most important to fill" (p. 6).

\section{Coastal Biomes Are Anthromes}

\subsection{Natural Ecosystems Embedded in Human Systems}

Terrestrial anthropic ecosystem processes (human-landscape interactions, more broadly) are a general function of population density, land use, biota, climate, terrain, and geology, where land use is dominated by industrial agriculture and the connectivity and conductivity of transportation networks [18,35]. Population density helps "distinguish situations in which humans may be considered merely agents of ecosystem transformation (ecosystem engineers), from situations in which human populations have grown dense enough that their local resource consumption and waste production form a substantial component of local biogeochemical cycles and other ecosystem processes" ([18], p. 440). Just as "global patterns of species composition and abundance, primary productivity, land-surface hydrology, and the biogeochemical cycles of carbon, nitrogen, and phosphorus, have all been substantially altered" ([18], p. 439) across the terrestrial biosphere, the same alterations apply to the liminal space of the planet's coasts and coastal oceans [2,5,6,36-38].

This commonality is true in part because anthropogenic coastal change is not mutually exclusive from anthropogenic terrestrial change. At river outlets, estuaries, and deltas, the coast receives the nutrient, chemical, and sediment confluence of upland land-use activities [26]. The very delivery of that anthropogenic confluence is itself anthropogenic, modulated by extraction, diversions, dams, hydraulic infrastructure, and other uses [39]. Affects of anthropogenic nutrient cycling on coastal biomes may be downstream extensions of terrestrial land use-anthropogenic hypoxic "dead zones" and contaminated groundwater are headline examples [26,40-43]. However, impacts from drivers that originate specifically at the coast also define coastal anthromes. "Global patterns of species composition and abundance [and] primary productivity" ([18], p. 439) identified on land have changed along coasts in equivalent ways as a result of overfishing in nearshore waters and continental shelves [28,29,44,45]; intensive urban and exurban coastal development, including the majority of the world's megacities [46]; and destruction (and indirect degradation) of coastal habitat types, including mangroves [47-49], seagrass meadows [50,51], marshes [52,53], estuaries [54], oyster beds [55], coral reefs [56,57], and kelp forests [58].

If "anthropogenic biomes tell a ... story ... of 'human systems, with natural ecosystems embedded within them"' ([18], p. 445), then coasts are a leading character in that story, undergoing an "inexorable transformation ... to a human artifact" ([59], p. 510). Efforts to quantify and map human impacts on the global ocean suggest that the notion of a natural coastal biome is moot $[3,4,37,60]$ : "the highest predicted cumulative impact" on marine ecosystems occurs "in areas of continental shelf and slope, which are subject to both land- and ocean-based anthropogenic drivers" ([3], p. 949). Synthesis of coastal systems and low-lying areas in the most recent IPCC report [5] explains that "coastal systems are subject to a wide range of human-related or anthropogenic drivers ... that interact with climate-related drivers and confound efforts to attribute impacts to climate change" (p. 372). The report emphasises, with "high confidence", that "human pressures on coastal ecosystems will 
increase significantly in the coming decades due to population growth, economic development, and urbanization" (p. 364). There is effectively no way to describe modern or future coastal systems without including humans as an integral component (Figure 1).

Table 1. Existing coastal biome/ecosystem classes, terrestrial anthrome groups, and coastal/marine stressors/impacts useful for informing an integrated coastal anthrome classification system.

\begin{tabular}{|c|c|c|c|}
\hline $\begin{array}{l}\text { Biomes \& Coastal } \\
\text { Natural Systems }\end{array}$ & $\begin{array}{l}\text { Anthromes \& Coastal } \\
\text { Human Systems }\end{array}$ & \multicolumn{2}{|l|}{ Coastal Impacts \& Threats } \\
\hline Goodall [61] & Ellis \& Ramankutty [18] & \multirow{52}{*}{$\begin{array}{l}\text { Halpern et al. [3] } \\
\text { impacts } \\
\text { nutrients (fertilizer) } \\
\text { organic pollutants } \\
\text { (pesticides) } \\
\text { inorganic pollutants } \\
\text { (impervious surfaces) } \\
\text { direct human } \\
\text { (population density) } \\
\text { fishing: pelagic, low } \\
\text { bycatch } \\
\text { fishing: pelagic, high } \\
\text { bycatch } \\
\text { fishing: demersal, } \\
\text { destructive } \\
\text { fishing: demersal, } \\
\text { non-destructive, low } \\
\text { bycatch } \\
\text { fishing: demersal, } \\
\text { non-destructive, high } \\
\text { bycatch } \\
\text { fishing: artisanal } \\
\text { oil rigs (benthic } \\
\text { structures) } \\
\text { invasive species } \\
\text { ocean pollution } \\
\text { shipping } \\
\text { ocean sea-surface } \\
\text { temperature } \\
\text { UV } \\
\text { ocean acidification } \\
\text { "missing" impacts } \\
\text { hypoxic zones } \\
\text { coastal engineering } \\
\text { (habitat alteration) } \\
\text { non-shipping cargo } \\
\text { (ferries, cruise ships) } \\
\text { aquaculture } \\
\text { disease } \\
\text { fishing: illegal, } \\
\text { unreported, unregulated } \\
\text { fishing: recreational } \\
\text { sedimentation change } \\
\text { freshwater input change } \\
\text { tourism } \\
\text { [historical data] } \\
\end{array}$} & \multirow{52}{*}{$\begin{array}{l}\text { Halpern et al. [23] } \\
\text { threats (see Figures 2-4) } \\
\text { freshwater input increase } \\
\text { freshwater input } \\
\text { decrease } \\
\text { sediment input increase } \\
\text { sediment input decrease } \\
\text { nutrient input into } \\
\text { oligotrophic system } \\
\text { nutrient input into } \\
\text { eutrophic system } \\
\text { pollutant input: } \\
\text { atmospheric } \\
\text { pollutant input: point } \\
\text { source, organic } \\
\text { pollutant input: point } \\
\text { source, nonorganic } \\
\text { pollutant input: } \\
\text { nonpoint source, organic } \\
\text { pollutant input: } \\
\text { nonpoint source, } \\
\text { nonorganic } \\
\text { coastal engineering } \\
\text { coastal development } \\
\text { direct human } \\
\text { aquaculture } \\
\text { fishing: demersal, } \\
\text { destructive } \\
\text { fishing: demersal, } \\
\text { nondestructive } \\
\text { fishing: pelagic, high } \\
\text { bycatch } \\
\text { fishing: pelagic, low } \\
\text { bycatch } \\
\text { fishing: aquarium } \\
\text { fishing: illegal, } \\
\text { unreported, unregulated } \\
\text { fishing: artisanal, } \\
\text { destructive } \\
\text { fishing: artisanal, } \\
\text { nondestructive } \\
\text { fishing: recreational } \\
\text { climate change: sea level } \\
\text { climate change: sea } \\
\text { temperature } \\
\text { climate change: ocean } \\
\text { acidification } \\
\text { climate change: UV } \\
\text { species invasion } \\
\text { disease } \\
\text { harmful algal blooms } \\
\text { hypoxia } \\
\text { ocean-based pollution } \\
\text { commercial activity } \\
\text { ocean mining } \\
\text { offshore development } \\
\text { benthic structures } \\
\text { ecotourism }\end{array}$} \\
\hline natural terrestrial & exurban population & & \\
\hline coastal wet & densities (persons per & & \\
\hline coastal dry & $\left.\mathrm{km}^{2}\right)$ & & \\
\hline aquatic (marine) & dense $(>100)$ & & \\
\hline intertidal \& littoral & residential (10-100) & & \\
\hline coral reefs & populated $(1-10)$ & & \\
\hline estuaries \& enclosed seas & remote $(<1)$ & & \\
\hline continental shelves & groups & & \\
\hline managed aquatic & dense settlements & & \\
\hline & $\begin{array}{l}\text { villages } \\
\text { croplands }\end{array}$ & & \\
\hline & rangelands & & \\
\hline & $\begin{array}{l}\text { forested } \\
\text { wild }\end{array}$ & & \\
\hline $\begin{array}{l}\text { Olson/WWF/Global } 200 \\
\text { [62] }\end{array}$ & IPCC [5] & & \\
\hline terrestrial & \multirow{38}{*}{$\begin{array}{l}\text { human systems } \\
\text { human settlements } \\
\text { industry, infrastructure, } \\
\text { transport, \& network } \\
\text { industries } \\
\text { fisheries, aquaculture, \& } \\
\text { agriculture } \\
\text { coastal tourism \& } \\
\text { recreation } \\
\text { health }\end{array}$} & & \\
\hline mangroves & & & \\
\hline freshwater & & & \\
\hline large river deltas & & & \\
\hline $\begin{array}{l}\text { temperate coastal rivers } \\
\text { tropical/subtropical }\end{array}$ & & & \\
\hline coastal rivers & & & \\
\hline oceanic islands & & & \\
\hline marine & & & \\
\hline polar & & & \\
\hline temperate shelves \& sea & & & \\
\hline temperate upwelling & & & \\
\hline tropical upwelling & & & \\
\hline $\begin{array}{l}\text { coral } \\
\text { IPCC [5] }\end{array}$ & & & \\
\hline natural low-lying & & & \\
\hline coastal systems & & & \\
\hline beaches, barriers, dunes & & & \\
\hline rocky coasts & & & \\
\hline wetlands, seagrass & & & \\
\hline coral reefs & & & \\
\hline coastal aquifers & & & \\
\hline estuaries, lagoons & & & \\
\hline $\begin{array}{l}\text { deltas } \\
\text { Halpern et al. [23] }\end{array}$ & & & \\
\hline $\begin{array}{l}\text { Halpern et al. [23] } \\
\text { coastal ecosystems }\end{array}$ & & & \\
\hline $\begin{array}{l}\text { loastal ecosystems (se } \\
\text { Figures 2-4) }\end{array}$ & & & \\
\hline intertidal rocky & & & \\
\hline intertidal mud & & & \\
\hline beach & & & \\
\hline mangrove & & & \\
\hline saltmarsh & & & \\
\hline coral reef & & & \\
\hline seagrass & & & \\
\hline & & & \\
\hline rocky reef & & & \\
\hline suspension-feeder reef & & & \\
\hline subtidal soft bottom & & & \\
\hline & & & \\
\hline soft shelf (30-200 m) & & & \\
\hline hard shelf $(30-200 \mathrm{~m})$ & & & \\
\hline
\end{tabular}




\subsection{Coastal Anthromes Are Mosaics}

Any attempt to classify and map anthromes confronts the reality that these physical areas are anything but homogenous units. As natural biome classifications have long acknowledged, many spaces are defined by their combinations of ecologies-and, in the context of anthromes, by their combinations of uses and impacts. Ellis and Ramankutty [18] note that "anthropogenic biomes are best characterized as heterogeneous landscape mosaics, combining a variety of different land uses and land covers" (p. 442). The same characterisation extends to coastal anthromes. Onshore, they share the same mosaics as existing terrestrial anthromes. Nearshore and offshore, their mosaics are manifest in the patchy footprints of physical geography, ecological communities, and in overlapping human uses of, and impacts on, marine space [3,33,63-67].

To paraphrase Ellis and Ramankutty [18] (pp. 442-443), coastal and terrestrial anthromes are mosaics for likely the same reasons: (1) even in the absence of humans, the biogeography of most natural landscapes is spatially heterogeneous; (2) humans tend to seek out and develop the most resource-rich, productive, and hospitable parts of landscapes first, reinforcing spatial patterns within natural biogeography; and (3) human cultural and social dynamics also create spatially heterogeneous settlement and transportation patterns unrelated to underlying biogeography. Throughout human civilization, coastal geography -including prevailing winds and currents-has steered maritime trade and transportation routes, first regionally, then globally, providing both an end (e.g., hotspots of natural resources) and a means (e.g., an efficient way to access distant places) [1,68]. However, natural marine geography is not the ultimate arbiter of human maritime patterns. The advent of engine technologies (steam and diesel) to supplant sails marks one departure from natural constraints; the feats of geoengineering that yielded the Suez and Panama Canals, completely rerouting maritime passages around the planet, marks another. Likewise, the extension of law into maritime space-and rights of use or access as a function of law - comes from geopolitical rather than natural boundaries [33]. The resulting global anthromic mosaic is itself a spectrum consisting of some anthromes defined by their underlying physical and biogeography and others by an unequivocally anthropogenic footprint (or overprint) of resource use.

\section{Toward Classifying Coastal Anthromes}

\subsection{Integrating Existing Classifications and Data Sets}

A first-order map of the world's coastal anthromes could derive from merging a selection of best-available global data sets and common classification frameworks for terrestrial and nearshore marine spaces. Following Ellis and Ramankutty's [18] original formulation for terrestrial anthromes based on human population, land use, and land cover, a classification scheme for coastal anthromes could include and adapt classifications of terrestrial and marine anthromes, biomes, and ecoregions (Table 1). Stitched together, the terrestrial and nearshore ribbons of these overlapping data sets should capture the salient patterns of the planet's coastal anthromes. A spatially explicit global coastal anthrome map is beyond the scope of this article, but this section: (1) presents potential routes toward formulating the classifications necessary to produce one; and (2) suggests some possible coastal anthrome types. Useful existing classification sets are listed in Table 1; a set of suggested coastal anthromes, spanning terrestrial anthromes and extending speculatively into "marine" anthromes, is shown in Table 2. 
Table 2. A proposed set of coastal (and marine) anthrome classes, based on the original classification by Ellis and Ramankutty [18].

\begin{tabular}{|c|c|c|}
\hline Terrestrial Anthromes [18] & Coastal Anthromes (Proposed Here) & Marine Anthromes (Speculative) \\
\hline & $<\sim 10$ m elevation & \\
\hline $\begin{array}{l}\text { dense settlements } \\
\text { urban } \\
\text { dense settlements }\end{array}$ & $\begin{array}{l}\text { dense settlements } \\
\text { urban } \\
\text { dense settlements }\end{array}$ & \\
\hline $\begin{array}{l}\text { villages } \\
\text { rice villages } \\
\text { irrigated villages } \\
\text { cropped \& pastoral villages } \\
\text { pastoral villages } \\
\text { rainfed villages } \\
\text { rainfed mosaic villages }\end{array}$ & $\begin{array}{l}\text { villages } \\
\text { rice villages } \\
\text { irrigated villages } \\
\text { cropped \& pastoral villages } \\
\text { pastoral villages } \\
\text { rainfed villages } \\
\text { rainfed mosaic villages }\end{array}$ & \\
\hline $\begin{array}{l}\text { croplands } \\
\text { residential irrigated cropland } \\
\text { residential rainfed mosaic } \\
\text { populated irrigated cropland } \\
\text { populated rainfed cropland } \\
\text { remote croplands }\end{array}$ & $\begin{array}{l}\text { croplands } \\
\text { residential irrigated cropland } \\
\text { residential rainfed mosaic } \\
\text { populated irrigated cropland } \\
\text { populated rainfed cropland } \\
\text { remote croplands }\end{array}$ & \\
\hline $\begin{array}{l}\text { rangelands } \\
\text { residential rangelands } \\
\text { populated rangelands } \\
\text { remote rangelands }\end{array}$ & $\begin{array}{l}\text { rangelands } \\
\text { residential rangelands } \\
\text { populated rangelands } \\
\text { remote rangelands }\end{array}$ & \\
\hline $\begin{array}{l}\text { forested } \\
\text { populated forest } \\
\text { remote forest }\end{array}$ & $\begin{array}{l}\text { forested } \\
\text { populated forest } \\
\text { remote forest }\end{array}$ & \\
\hline \multirow[t]{10}{*}{$\begin{array}{l}\text { wildlands } \\
\text { wild forest } \\
\text { sparse trees } \\
\text { barren }\end{array}$} & $\begin{array}{l}\text { wildlands } \\
\text { wild forest } \\
\text { sparse trees } \\
\text { Barren }\end{array}$ & \\
\hline & $\begin{array}{l}<200 \text { m depth } \text { OR }<200 \mathrm{~nm} \text { offshore } \\
\text { (Limit of EEZ) }\end{array}$ & $\begin{array}{l}>200 \mathrm{~m} \text { depth OR }>200 \mathrm{~nm} \\
\text { offshore (Limit of EEZ) }\end{array}$ \\
\hline & $\begin{array}{l}\text { direct human } \\
\text { industrial complex }\end{array}$ & $\begin{array}{l}\text { direct human } \\
\text { maritime use mosaic }\end{array}$ \\
\hline & $\begin{array}{l}\text { coastal engineering } \\
\text { tourism \& recreation mosaic } \\
\text { inshore/nearshore maritime use mosaic }\end{array}$ & $\begin{array}{l}\text { offshore fisheries } \\
\text { intensive pelagic fishing } \\
\text { deep-sea demersal fishing }\end{array}$ \\
\hline & terrestrial input zones & low-intensity offshore fishing \\
\hline & $\begin{array}{l}\text { inshore sediment/nutrient/pollutant inputs } \\
\text { nearshore sediment/nutrient/pollutant } \\
\text { mixing }\end{array}$ & $\begin{array}{l}\text { benthic infrastructure } \\
\text { seabed mining } \\
\text { oil rigs }\end{array}$ \\
\hline & aquaculture & wind farms \\
\hline & $\begin{array}{l}\text { high-pollution inshore aquaculture } \\
\text { low-pollution inshore aquaculture } \\
\text { onshore aquaculture } \\
\text { nearshore aquaculture }\end{array}$ & ocean wildlands \\
\hline & $\begin{array}{l}\text { fisheries } \\
\text { intensive inshore demersal fishing } \\
\text { intensive inshore non-demersal fishing } \\
\text { low-intensity inshore fishing } \\
\text { intensive nearshore demersal fishing } \\
\text { intensive nearshore non-demersal fishing } \\
\text { low-intensity nearshore fishing }\end{array}$ & \\
\hline & coastal wildlands & \\
\hline
\end{tabular}




\subsubsection{Terrestrial Anthromes}

What constitutes "coastal" terrestrial area? The IPCC [5] defines the Low Elevation Coastal Zone (LECZ) as anything below the global 10 m elevation contour, a belt that "constitutes $2 \%$ of the world's land area but contains 10\% of the world's population (600 million)", and, based on year 2000 estimates [69], also contains "13\% of the world's urban population (360 million)" [5] (p. 372). Starting with a global digital elevation model (DEM) and selecting all terrain below $10 \mathrm{~m}$ elevation would define the inland spatial bounds of coastal anthromes. A secondary rule, perhaps based on proximity to a shoreline, might need to account for high-standing coastal cliff systems-reaches of coast above $10 \mathrm{~m}$ elevation that are still anthromic, such as intensively farmed, grazed, or densely developed clifftops (Figure 1C). The elevation-derived boundary used to define the terrestrial "coast" can then be used to mask the existing map of terrestrial anthromes by Ellis and Ramankutty [18]. That map includes six anthrome groups (dense settlements, villages, croplands, rangelands, forested, and wild; each group comprises subtypes) based on four densities of exurban human population (persons $\cdot \mathrm{km}^{-2}$ ), distinguished by orders of magnitude (dense: >100; residential: 10-100; populated: 1-10; remote: $<1$ person $\cdot \mathrm{km}^{-2}$ ).

Broadly posed, classifications of dense settlements within the band of coastal landscape lying at or below $\sim 10 \mathrm{~m}$ elevation should require minimal translation. Coastal villages could be parsed by Goodall's [61] classification of "coastal wet" and "coastal dry" natural terrestrial ecosystems; by their spatial situation within the Global 200 coastal "freshwater biomes" of large river deltas, temperate/tropical/subtropical coastal rivers, and oceanic islands (in the Global 200, mangroves are a terrestrial biome) $[61,62,70]$; or by local proximity to shorelines characterized by intertidal rock, mud, beach, saltmarsh, mangrove, or reef [23]. Terrestrial coastal croplands would include any agricultural production (below $\sim 10 \mathrm{~m}$ elevation) bordered by a coastline, and the same would apply to terrestrial coastal rangeland, such as grazed cliff tops [71] and upper marshes [72,73]. Forested coastal anthromes might include mangroves [74], maritime forests (such as those typical of temperate barrier islands and marsh uplands), and standard forest types (boreal, temperate, tropical, subtropical) that reach the coastline. Finally, wild coastal anthromes might be defined by exceptional distance from nearest direct human impacts [3]. Conceivably, delineation of these anthomes could also be informed by aspects of the Dynamic Interactive Vulnerability Assessment map (DIVA), a global database of natural coastal system and socioeconomic factors (e.g., landform type, tidal range, wave climate, storm surge height, per-capita GDP, tourism flux) and data-driven model scenarios for climate-change impacts and adaptation [75].

A coastal anthrome classification would thus require including the existing classes of terrestrial anthrome types and making additions to them, such as where coastal forest has been converted to onshore penned aquaculture (e.g., Figure 1B), or where expansive land reclamation is responsible for the seaward edge of the coastal zone over extended spatial scales (tens of $\mathrm{km}$ ) (see Section 4.4). Onshore aquaculture, along with various forms of "direct human" coastal anthromes (e.g., industrial complexes, coastal engineering, tourism and recreation mosaics-see Table 2) are not necessarily mutually exclusive from existing terrestrial anthrome types (e.g., "cropped and pastoral villages", "urban/dense settlements") and may be distinguishable only at high spatial resolution. Classifying activities specific to shorelines and fundamentally reliant on a land/sea interface are an inherently complicated-but potentially rewarding — aspect of adding coastal anthromes to the original set. (Such challenges and opportunities are further discussed in Section 4.)

\subsubsection{Inshore and Nearshore Coastal Anthromes}

A quintessential characteristic of coastal environments is the transitional physical space they span between onshore and offshore- $\mathrm{a}$ transition that translates into resource use. For example, a number of intertidal and nearshore coastal environments arguably function as croplands or rangelands. If "crop" implies a harvestable commodity that is stationary once planted, then a coastal cropland anthrome might include all forms of penned aquaculture, faunal (e.g., oysters and other saltwater molluscs, 
crustaceans) [76-79], non-faunal (e.g., seaweed farming) [80], and even mineral (e.g., salt pans [81]). If "range" implies an agricultural resource that is free to roam (perhaps within a prescribed area), then a coastal rangeland anthrome might include mudflats harvested regularly for fauna such as bloodworms, sandworms, and clams [82]; intertidal zones harvested for algae and glassworts [83]; arrays of penned pelagic fish [84,85]; and concentrated inshore trap fishing (e.g., American lobster) [86].

Farther offshore, anthropogenic pressures on kelp, reef, and shallow shelf environments are dominated by fishing activities [3,4,23], but links to terrestrial analogues persist. For example, modern and historical bottom trawling-ubiquitous on the planet's shallow shelves-has been likened to forest clear-cutting (in the extreme) [45] and ploughing (with comparable geomorphic effects) [87]. Classification of these offshore systems might distinguish between fishing anthromes characterized by different general methods, especially destructive versus non-destructive, versus others more affected by development and industrial works, such as aggregates mining (and spoil dumping), high-density zones of shipping traffic, turbine arrays, and oil and gas platforms. (In some circumstances, footings and anchors for turbines and platforms can function like artificial reefs [88,89].) Hypothetically, some of these offshore coastal classes would extend into deep-water, marine anthromes (Table 2).

\subsection{Identifying and Distinguishing Coastal Anthromes}

With terrestrial anthromes mapped on landward side of the land-sea interface [18], the quantitative map of human impacts on marine ecosystems by Halpern et al. [3] offers a starting place for defining inshore and nearshore anthromes on the seaward side. Embedded in that global analysis [3] is a map of "marine ecoregions of the world" (MEOW) [90], which defines "coastal" areas of the global ocean as all marine waters either: (1) shallower than $200 \mathrm{~m}$ depth (thus including major reefs, banks, and seamounts); or (2) $370 \mathrm{~km}(200 \mathrm{~nm})$ offshore of a terrestrial territorial boundary, the approximate limit of the Exclusive Economic Zone (EEZ). Halpern et al. [3] convert "impact weights" for "17 anthropogenic drivers of ecological change" into component and cumulative impact scores. Impacts are not anthromes, but these impacts-and the longer list of categorical ecosystem "threats" from which they derive (Figure 2) [23] — tend to occur in clusters that change as a general function of ecosystem type (Figure 3). Examining those groupings is a step toward identifying salient, generalisable classes of coastal anthromes (Table 2).

For example, Figure 2A reproduces the "ecosystem vulnerability" table of intertidal and coastal ecosystems and threats by Halpern et al. [23] (which underpins the global map of human impacts on marine ecosystems [3]). Figure 2B ranks the ecosystems across threats and Figure 2C ranks threats across ecosystems in terms of respective cumulative impact scores. Rocky reef and hard shelf ecosystems are the most vulnerable coastal ecosystems in this accounting (Figure 2B), with moderate to high scores distributed across a large number of potential threats, especially those related to fishing and climate change. Ice, beach, and kelp-forest ecosystems appear to be the least vulnerable by comparison, but threats to ice and beach ecosystems return notably high scores (Figure 2C): coastal development and direct human impacts have scores disproportionately higher than the rest, followed by a cluster of systemically related threats (increased sediment input, coastal engineering, species invasion, and organic point-source pollutants) and global climate-related changes (sea level and temperature).

These scores and rankings invite further categorical parsing. Figure $3 \mathrm{~A}-\mathrm{N}$ shows ranked threat scores for each of the ecosystems listed in Figure 2. Threats labelled in each panel constitute the top $50 \%$ of the total (cumulative) threat score for that ecosystem (Figure 2B). Figure 30 ranks the ecosystems according to the number of threats that contribute to their $50 \%$ totals, from lowest (ice $=4$ threats) to highest (rocky reef $=13$ threats). Figure $4 \mathrm{~A}$ presents this subset of threats per ecosystem as a recast version of Figure $2 \mathrm{~A}$, filtered to show only the top 50\% contributing threats. Figure $4 \mathrm{~B}$ ranks the ecosystems by coefficient of variance $(C V$, the ratio of the standard deviation to the mean, based on the full data matrix in Figure 2A). This metric corresponds approximately with the ranking in Figure $3 \mathrm{O}$, but utility of $C V$ is that it better reflects the extent to which a given ecosystem is dominated by a few specific, high-scoring threats (resulting in a high $C V$, such as for ice, kelp-forest, and beach 
systems), or is affected by several threats of similar magnitude (resulting in a low $C V$, such as for saltmarsh, soft shelf, and rocky reef systems). Finally, Figure 4C ranks the prevailing threat types (Figures 3 and $4 \mathrm{~A}$ ) by their frequency of occurrence across the ecosystems. This step demonstrates that some threats (e.g., direct human impacts, coastal development and engineering, changes in sea level and temperature, and increased sediment input) are nearly ubiquitous across all 14 intertidal and coastal ecosystems. This "universal" common set could serve as a sort of blank against which to test for relative impacts in specific locations. Much like a mass spectrometer measures the elemental signatures within a bulk sample, it might be possible to measure the normalised strength or character of anthropogenic influence-a nuanced anthromic fingerprint-in one anthrome relative to another.
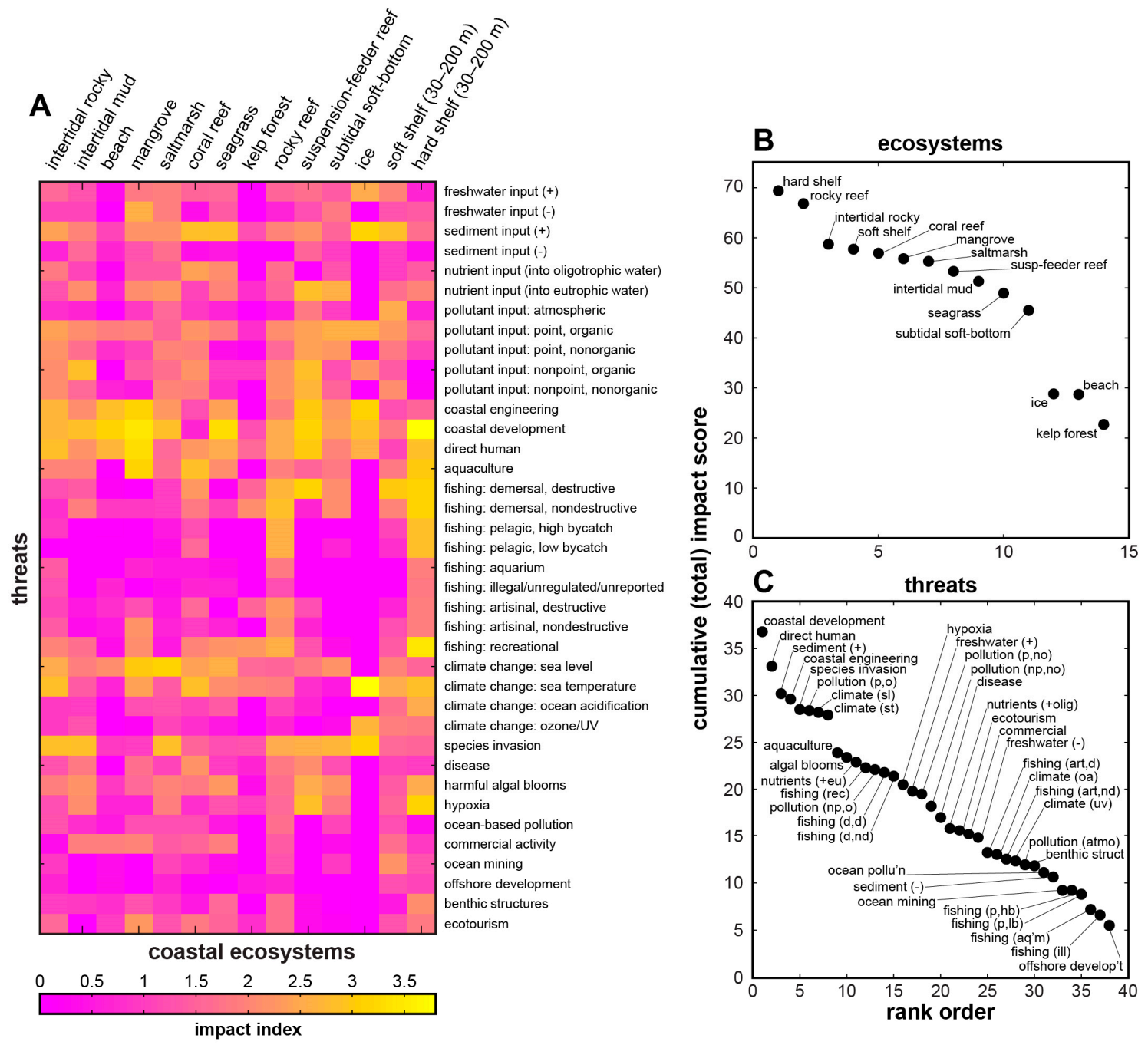

Figure 2. Coastal ecosystems and threats adapted from Halpern et al. [23]: (A) table of impact scores per ecosystem, shown by relative intensity; (B) ecosystems ranked by cumulative (total) impact score across threats; and (C) threats ranked by total impact score across coastal ecosystems. 

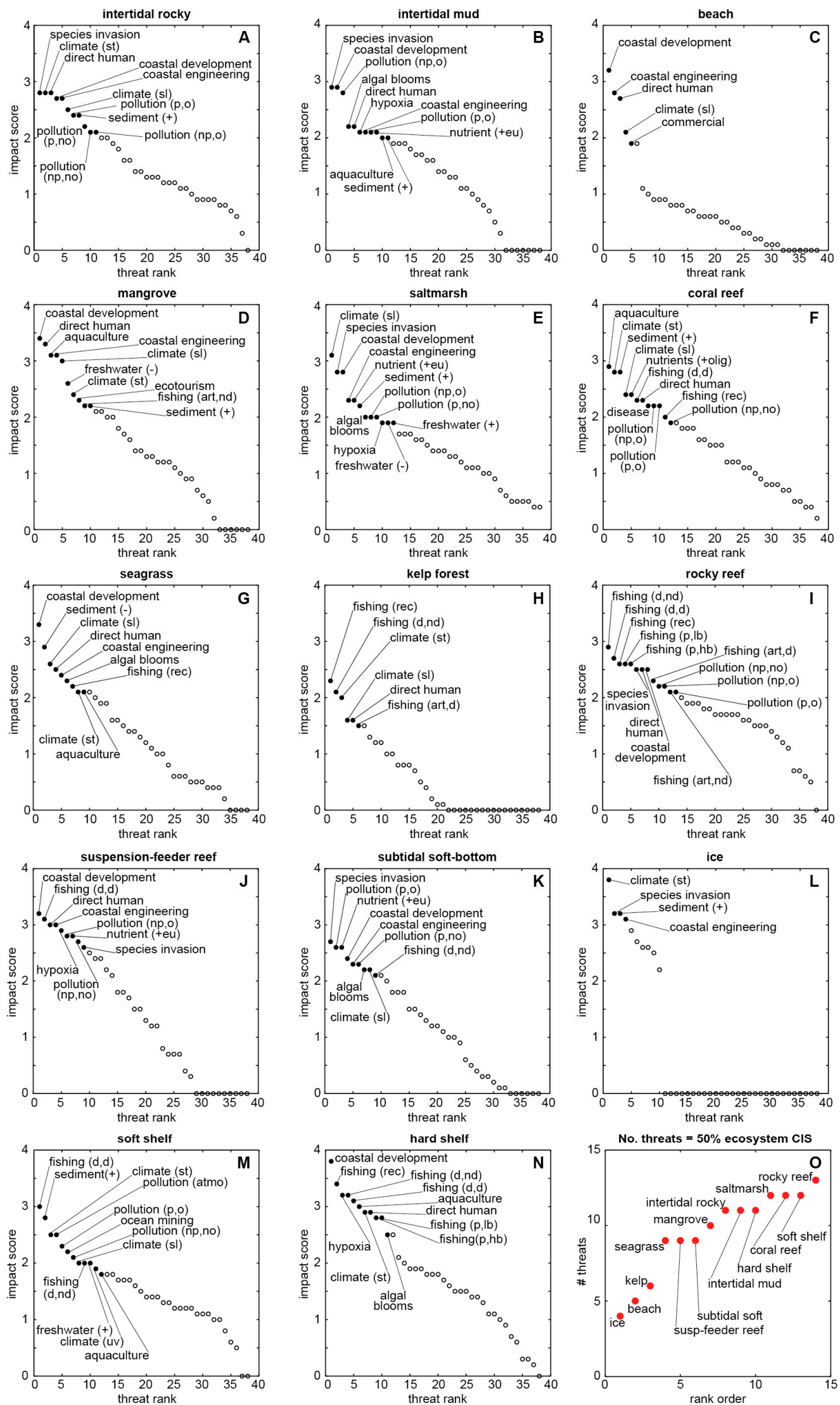

Figure 3. (A-N) Ranked threats per coastal ecosystem (Figure 2A). Labelled threats, when summed, account for the top $50 \%$ of the total threat score for a given ecosystem (Figure 2B). (O) Ecosystems ranked (lowest to highest) by number of threats that contribute to the $50 \%$ totals in panels (A-N). 

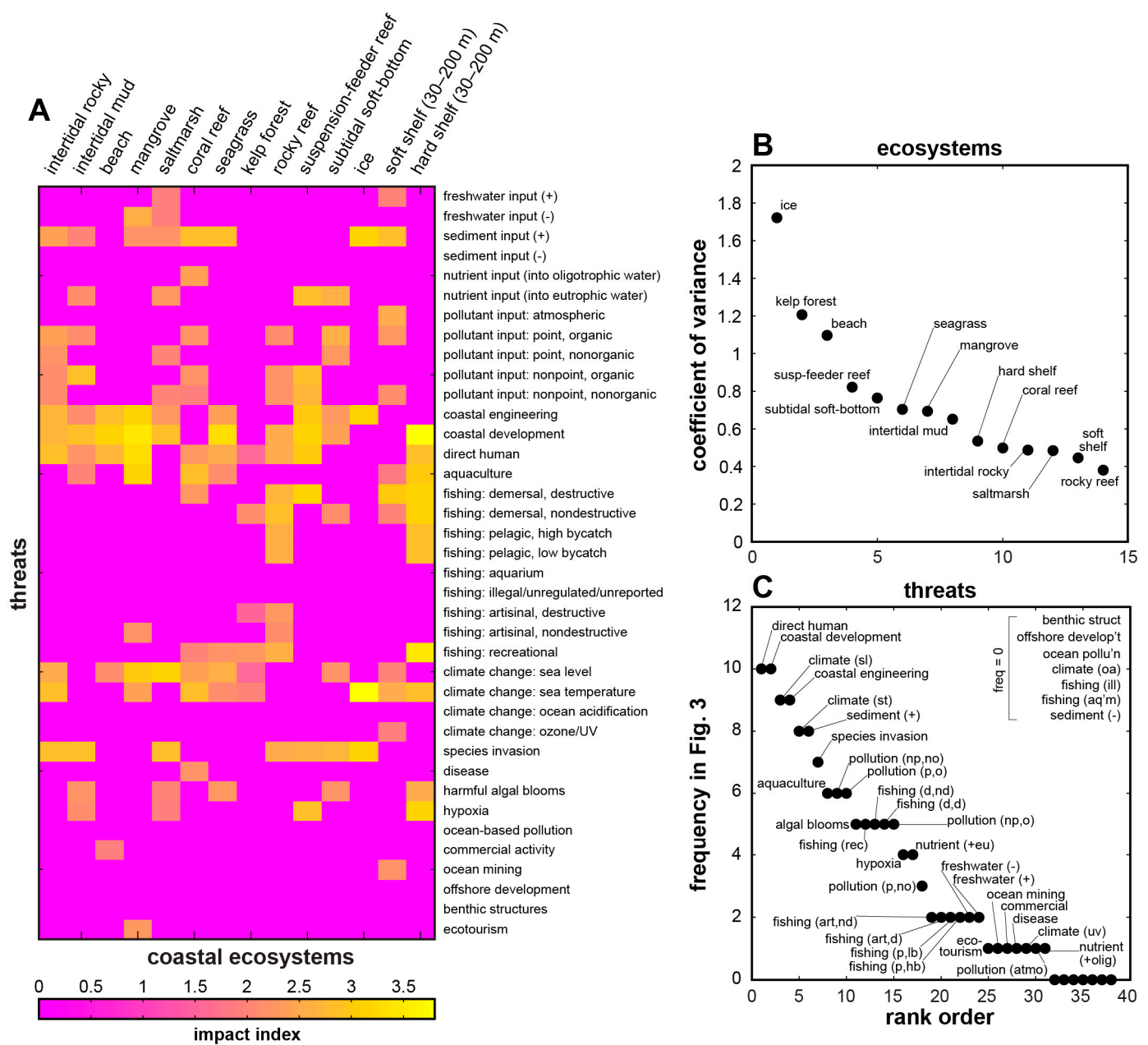

Figure 4. (A) Matrix of coastal ecosystems and threats in Figure 2A, filtered by top contributors identified in Figure 3A-N. (B) Ranked coefficient of variance (ratio of standard deviation to the mean) per coastal ecosystem across threats, calculated from the full data matrix in Figure 2A. (C) Ranked frequency of occurrence across ecosystems for contributing threats labelled in Figure 3A-N.

A complementary means by which to define coastal anthromes in particularly heterogeneous zones of ecosystems and threats is through Ellis and Ramankutty's [18] three testable hypotheses for anthrome veracity:

1. that "anthropogenic biomes will differ substantially in terms of basic ecosystem processes ... and biodiversity ... when measured across each biome in the field, and that these differences will be at least as great as those between the conventional biomes when observed using equivalent methods at the same spatial scale";

2. that "these differences will be driven by differences in population density and land use between the biomes..." ; and

3. that "the degree to which anthropogenic biomes explain global patterns of ecosystem processes and biodiversity will increase over time, in tandem with anticipated future increases in human influence on ecosystems" ([18], p. 445).

Following their first global map of human impacts on marine ecosystems published in 2008, Halpern et al. [4] measure how those impacts changed between 2008 and 2013. Although "cumulative impact across all stressors is generally increasing," Halpern et al. [4] find pronounced changes "especially in coastal areas where human uses of the ocean are the greatest" (p. 4). They report that 
"nearly $66 \%$ of the ocean experienced increases in cumulative impact over the 5-year study span", and that "increases tended to be located in tropical, subtropical and coastal regions, with average increases in 77\% of all [EEZs]" (pp. 2-3). Overall, "increases in climate change stressors (sea surface temperature anomalies, ocean acidification and ultraviolet radiation) drove most of the increase in cumulative impact" (p. 3), but, consistent with Ellis and Ramankutty's [18] second hypothesis, "countries with greater increases in coastal population had larger 5-year changes in cumulative impacts" (p. 3). Furthermore, "land-based stressors all increased globally ... but these increases were concentrated in coastal areas of only $27 \%-52 \%$ of all EEZs" (p. 3). Onshore and inshore environments are most vulnerable to compounded effects of direct human impacts, including development and engineering, related pollution inputs and responses to nutrient loading (harmful algal blooms, hypoxia), industrial commercial activity, and aquaculture conversion (Figures 2 and 3) [3,4,23].

Although informed by the categorisations in Table 1 and by the rank-ordering steps shown in Figures 2-4, the list of potential coastal anthrome groups and types in Table 2 is perhaps most useful as a point of departure for further investigation. Data gathering, integration, and mapping (especially in regions of the world where data coverage is best) will begin to reveal whether a given coastal anthrome type is redundant, impossible to resolve, or whether one or more patterns in the data suggest the expression of a type as yet unlisted. Beyond that, explicit mapping will allow calculation of extent, distribution, and relative proportion for each anthrome type, as has been demonstrated for terrestrial anthromes [18] and marine impacts [3].

\section{Challenges of Historical Legacy in Coastal Novel Ecosystems}

\subsection{Of Footprint and Function}

Mixed-ecology, mixed-use spaces are difficult not only to group into a set of descriptors, but also to resolve empirically. Progress on the problem remains data-limited [34]. As Halpern et al. [3] explain, "anthropogenic drivers that could not be included" within their global marine analysis (which remains the definitive work to date) "are, among others: hypoxic zones, coastal engineering (piers, rock walls, etc.), non-cargo shipping (ferries, cruise ships, etc.), aquaculture, disease, recreational fishing, changes in sedimentation and freshwater input, and tourism. For all of these drivers data exist for one or more regions, but none have full global coverage" (SOM, p. 1). They add that "most of these activities primarily affect intertidal and nearshore ecosystems rather than offshore ecosystems, which suggests that our estimates for nearshore areas are particularly conservative", especially because "some drivers may have synergistic effects" (p. 951) that cumulatively amplify their additive, respective impacts [91].

Furthermore, Halpern et al. [3] offer the caveat that their analysis of human impacts on marine ecosystems does not explicitly account for historical hysteresis-places where "many changes occurred in the past with lasting negative effects, but the drivers no longer occur at a particular location" (p. 951). Modelled reconstructions of ancient and historical land use have begun to inform maps of terrestrial anthromes $[19,92,93]$, but there are no equivalent, quantitative global reconstructions of cumulative ancient and historical marine use. The information from which to develop even a simplified model is spread across a variety of disciplines, including maritime history [1,68], geography [32,94], fisheries [28,95], marine science [3,4,23], and global climate simulation [96].

Legacies of past use $[6,28,37,60,95,97,98]$ matter especially with regard to the emergence of novel ecosystems, and in turn for mapping the anthropogenic biosphere. As Ellis [19] explains, "land-use patterns emerge as a complex path-dependent function of pre-existing natural variations in landscapes, human population dynamics, technologies, economic systems and their ecological results, all interacting strongly over time and space, with the duration of human occupation producing a strong legacy effect" (pp. 1016-1017). Legacy introduces new knots to the problem of disentangling drivers from stressors [34], and therefore the problem of determining what kind of anthrome exists where. If a driver is an activity (e.g., demersal trawling), then a stressor is the effect of that activity (e.g., habitat disturbance). Empirical information regarding the states and behaviours of coastal and 
marine systems tend to be a patchwork of activities and stressors, and one data type is often used to infer or model information about the other [34]. In the case of demersal trawling, the mapped footprint of the activity (where the trawlers fish) may match the mapped footprint of the consequent stressor (where habitat is disturbed), but not all drivers and stressors-terrestrial farming and coastal nutrient loading, for example [26,34]—are so spatially correlated. In places where effects persist long after a driver is gone, should the attribution of an anthrome classification somehow be defined by the absence of something that would be there otherwise-oyster reefs along the US Eastern Seaboard, for example [55]—were it not for some past anthropogenic perturbation?

\subsection{Three Anthropogenic Pathways to Novel Ecosystems}

Erasing an extant, natural ecosystem through intensive resource use and extraction is an obvious way to make room, if unintentionally, for a novel ecosystem [36,60]. In coastal contexts, use intensity might substitute for "duration of human occupation," especially where human disturbance recurs on a time scale much faster than natural processes of disturbance and recovery [45].

A novel ecosystem may also arise in response to systemic changes within an ecological community, such as intrinsic adjustments to extrinsic impacts on trophic webs [29,97]. A classic example of this phenomenon is the predator-prey-habitat relationship between otters, urchins, and kelp [58,99,100]. On the West Coast of North America, humans overhunted otters for the European fur trade of the late 1700 s and early 1800s, removing otters as an apex predator and triggering a population boom among sea urchins. Unchecked, urchins overgrazed kelp forests, resulting in expansive, persistent "urchin barrens". Northeastern Pacific kelp forests and urchin barrens exemplify end-members of an ecosystem with alternative stable ecological states, in which otters (or urchin predators, more generally) function as the fulcrum. Historical human impact inadvertently pushed the system toward one state; current conservation interventions now work to push the system toward the other, preferred state [101].

A third, if less common, novel-ecosystem pathway is through habitat creation. As otters were being hunted out of the North American Pacific Northwest, European settlement expansion on the opposite side of the continent was driving extensive deforestation across the Atlantic Northeast [102]. Cores from salt marshes reflect a huge pulse of sedimentation coincident with that period [103], suggesting that prior to European arrival, northeastern marsh systems had smaller spatial footprints. Such marshes are now regarded as critical habitats for the biodiversity they support, the storm protection they afford, and other ecosystem services they provide [104]. In this context, habitat erasure and creation may be two sides of the same resource-use coin.

An underlying, fourth pathway to a novel ecosystem is through climate change, held apart in this discussion because it arises even without anthropogenic drivers [19]. For example, consider an ecotone: the geographic boundary space in which one biome transitions into another, such as between temperate and boreal forest, or boreal forest and taiga. If, under changing climate conditions, the ranges of those biomes adjust at different velocities (e.g., if the southern boundary of the boreal forest biome moves north faster than the northern boundary of the temperate forest) [105], then the physical space of the ecotone may widen, leaving room for the opportunistic pioneer species of a nascent novel ecosystem [106,107]. Recent work shows that marine taxa track local climate change velocities, and that climatic shifts predict patterns of taxa change better than species characteristics or life histories [108]. Past climate change occurred in the absence of industrialised humanity, but natural range-shift responses to modern climate change now must contend with terrestrial and marine landscapes fragmented by development, use, and regulation $[107,109,110]$. Climate change is a diffuse, large-scale forcing with demonstrable impacts on ecosystem function and footprint [3,4,19] and may exacerbate conditions under which anthropogenic novel ecosystems arise [19], but modern climate change may be necessary but not sufficient as a system characteristic with which to define an anthrome (Figures 2 and 4). 


\subsection{Coupled Human-Natural Systems}

Human activities may be driven or dominated by environmental conditions [15,111], although the converse is more common [2]. Both relationships qualify as unidirectional human-natural systems, wherein one component simply drives the other: humans might migrate with climate changes in order to stay within habitable conditions $[15,111]$; humans might also reroute a subcontinental-scale river system to deliver water to a desert landscape [112,113]. However, an enigmatic relationship between human activities and the natural environment is reciprocal: the human and environment systems are "coupled" through nonlinear feedbacks, such that the behaviour of each subsystem is a dependent function of the other. The dynamics of the coupled system are emergent, unfolding and interacting temporal and spatial scales hierarchically larger than their respective components, and in ways insensitive to the underlying mechanics operating at fine scales [114,115]. Coupled environmental systems are a central conceptual tenet of classical geography $[116,117]$, but new efforts to gain quantitative insight into their dynamics is spurring a renaissance of inquiry, empirical and theoretical, across a range of disciplines [110,115,118-122].

This renaissance is relevant to coastal anthromes because some of the best examples of coupled human-environment systems are coastal. Coupled systems also demonstrate another means by which sustained human manipulation or modification of a given environment can result, unintentionally or indirectly, in the development novel ecosystems. Furthermore, they represent physical settings that are quintessentially anthromic: landscapes and ecosystems that look and change the way they do because of mutually responsive interactions between human activities and natural processes. Three system exemplars help illustrate this point: (1) the inshore American lobster fishery; (2) urbanised deltas; and (3) beach nourishment.

\subsubsection{The "Wild" Monoculture of Inshore American Lobster}

The inshore fishery for American lobster along the North Atlantic coast of Maine, USA, involves using fixed-gear traps to harvest a wild-caught organism. The fishery has been described as both a complex adaptive system based on lobster as a common-pool resource [123], but also as a kind of hybridised aquaculture in which the inshore lobster ecosystem, neither natural nor explicitly cultivated, functions like a monoculture [86]. The density of traps fished during summer months in Maine's tidal river systems and nearshore zones effectively feeds and supports, through strict regulations, a lobster population far larger than would exist otherwise.

Traps are designed with an inherent ineffectiveness, so that lobsters up to a certain size may crawl in and out; large numbers of baited traps thus provide food for many more individuals than they ever catch [124]. High market prices for lobster relative to other catches reinforces a type of coupled social-ecological system called a "gilded trap", with "reinforcing feedbacks between social and ecological systems in which social drivers (e.g., population growth, globalization, and market demand) increase the value of natural resources as the ecological state moves closer to a tipping point ... " [86] (p. 905). What "moves" that ecological state is the growth of the "wild" monoculture at the expense of higher diversity across the marine ecosystem. The monoculture becomes vulnerable to disease and population crash-and with that, the socio-economic collapse of the fishery. Such collapse differs from one driven by sustained overfishing, as occurred for cod in the same geographic region, with a subsequent moratorium for the cod fishery [125]. The gilded trap functions like a market bubble, in that high prices further inflate the market, along with participation in it, socioeconomic dependence on it, and the incongruous ecological footprint of it. Meanwhile, the actual value of the commodity-here, the collective health of the lobster population, and of the ecosystem it comes to dominate- - begins to decline.

Gilded traps are not a strictly modern phenomenon. An analogous, historical coastal trap may explain why Norse settlement in Greenland collapsed in the 15th century [126,127]. Rather than getting pushed out by a marked climatic shift or by overharvesting the seals and walrus on which they depended for subsistence and trade goods, Norse settlers may have abandoned their foothold on 
Greenland for socioeconomic reasons: the devaluation of walrus ivory, a mainstay of Norse economic activity in Greenland; a concomitant decline in shipping traffic from Iceland and Norway; and aggressive competition for territory by Inuit peoples. Dugmore et al. [126] (who use the term "rigidity trap") present a resonant summary of the Norse Greenland system: "The choices made by the Norse in Greenland, to invest in fixed resource spaces and social and material infrastructure and intensify marine resource use, increased the effectiveness of adaptation and minimized landscape impacts but at an apparent cost of reduced resilience in the face of 15th century conjunctures. In effect, their concentration on certain marine mammals for subsistence and a highly integrated communal approach to both subsistence and economic activity (the focus on the spring seal hunt and the harvesting and processing of prestige goods, particularly ivory) were effective in the short term; they could be refined to cope with a degree of change over centennial time scales but developed into a rigidity trap on the millennial scale that ultimately lacked resilience in the face of the changing world system and conjunctures" (p. 3362).

Given their self-reinforcing dynamics [128], marine monocultures may represent a class of coastal anthromes unto themselves. They almost certainly function as precursors to subsequent coastal anthromes.

\subsubsection{Urbanised Deltas}

Theorising the dynamics of coupled human-landscape systems, Werner and McNamara [115] argue that "humans-landscape coupling should be strongest where fluvial, oceanic or atmospheric processes render significant stretches of human-occupied land vulnerable to large changes and damage, and where market processes assign value to the land and drive measures to protect it from damage. These processes typically operate over the (human) medium scale of perhaps many years to decades over which landscapes become vulnerable to change and over which markets drive investment in structures, evaluate profits from those investments and respond to changes in conditions" (p. 399).

To demonstrate these dynamics, Werner and McNamara [115] model the historical development of New Orleans, Louisiana (USA), near the deltaic terminus of the Mississippi River. The delta landscape floods during storm events, and flood severity is a combined function of storm magnitude, land subsidence, and marsh loss through coastal erosion. Flooding damages city property and infrastructure, spurring levee construction along the banks of the river. Levees channelize the delta, starving the distal marshes of sediment supply and resulting in marsh loss. One consequence of channelization and marsh loss is an effective increase in storm impact severity for a given storm magnitude [129]. More storm damage drives further investment in levee construction, exacerbating the damage-mitigation feedback. These dynamics extend beyond New Orleans to urbanised deltas around the world $[130,131]$.

Ultimately, "the long-time-scale dynamics of the modelled system appears to be characterised by an attractor with emergent dynamics in which small scale floods are filtered out at the expense of amplifying the impact of large floods to be significant disasters, because protection from small scale floods facilitates development in areas prone to disaster and increased channelization causes an increase in flood size that results in enhanced damage from the low frequency flood events" ([115], p. 404). The coupled system behaves and evolves in a way fundamentally different from its constituent human and natural parts in respective isolation or otherwise treated in parallel.

When defined by its distinctive dynamics, such a system can only be an anthrome. However, coupled systems exemplify the methodological problem of inducing system function from component footprints. Classification demands that spatial boundaries be delineated, yet coupled relationships are all but invisible in static source data. Information about system function and internal dynamics is key to accurately representing coupled systems among anthromes [34]. For all their utility, static maps of land uses (e.g., coastal development and infrastructure) and land covers (e.g., fluvial channels, salt marsh) do not capture a coupled system's emergent spatial scale of interactions across its component 
land uses and types, and thus are limited in their ability to resolve the bounds of a coupled-system anthrome best described by the (likely larger) spatial footprint of its dynamics.

\subsubsection{Beach Nourishment and Developed Coastlines}

Because most developed or intensively managed coastlines have high market values and are defended against coastal hazard, developed coastlines meet the criteria of a tightly coupled system [110]. By extension, they exhibit dynamical behaviours distinct from those of natural coasts $[27,132-135]$, with ecological ramifications not necessarily reflected in coastal population density. This complication makes them an intriguing potential anthrome type.

Beach nourishment is a coastal engineering practice that involves importing sand from outside the immediate littoral system to mitigate chronic or storm-driven shoreline erosion. A "soft engineering" alternative to shoreline hardening through seawalls, groynes, and rock armouring, beach nourishment has been the preferred mode of shoreline protection in the US since the 1970s [136] and has proliferated in Europe [137]. However, these targeted sand deliveries are ephemeral: natural, wave-driven processes of sediment transport rapidly redistribute nourishment sand offshore and alongshore. Towns that rely on beach and dune nourishment for hazard protection typically require a long-term replenishment schedule every few years [136,138].

Beach nourishment can initiate the development of a coupled system because, in popular tourist destinations, beach width is a form of natural capital: a wide beach is worth money, financial capital that gets folded into ocean-view property values, hotel and restaurant prices, and various other amenities. Modelling work suggests that coastal interventions can have subtle but important nonlocal effects. Nourishment in one location can affect beach widths elsewhere along the coast, sometimes over significant distances. For extended reaches of coast dominated by development and carved into separate towns or municipalities, the spatio-temporal behaviour of the beach in each town may become a function of management decisions among its neighbours [27,133,139].

Despite the ubiquity of its application, the long-term ecological effects of repeated beach nourishment and dune construction are largely unknown [140]. Nourishment smothers natural communities of beach-dwelling invertebrates, and, by introducing high volumes suspended sediment to the nearshore zone, impairs the feeding effectiveness of fish that forage and hunt in the surf zone [141-143]. Sand size, texture, and colour can vary depending on its source, and where nourished beaches are also nesting habitats for sea turtles, characteristics of nourishment sand can affect nesting success, clutch survival, and hatching sex distributions [144-147]. Repeatedly rebuilt dunes may lack the topographic heterogeneity conducive to sheltered or niche habitats, and may host less biodiversity than their natural counterparts $[140,147,148]$. Even soft-engineering mitigation against coastal erosion can obstruct the physical processes necessary for habitat creation. By design, artificial dune crests tend to prevent barrier breaching and overwash-the storm-driven flows that transport of sand from the beach face to the top and back of a coastal barrier-but fresh sediment deposition and shallow burial via overwash is critical for some dune [149] and marsh [150] vegetation, and for nesting birds [151]. Research into the economics of beach nourishment suggests that wealthier towns have an economic incentive to nourish more frequently $[152,153]$, which could tend to exacerbate negative changes to beach ecologies in wealthier development zones.

Developed coasts driven by tourism economies and locked into cycles of beach nourishment [152] may ultimately represent another form of gilded trap [86,128]. Where tourism revenue, real-estate, and proximity to natural amenities drives up property values [153] and encourages investment in further development, that development in turn creates a demand for investment in protection against inherent natural hazard [154]. Once initiated, coastal development and nourishment may spur a positive feedback, such that development concentrates in nourished zones [155]. If a tourism industry grows at the expense of more varied local economies, [156-158], the region becomes more vulnerable to economic downturns [159] and other external shocks, just as a monoculture grows increasingly vulnerable to disease or other disruptions. However, the gilded trap of coastal development persists in part because 
the economic benefits are consistently high enough (at least during a "boom" period) to reinforce rather than discourage the development-protection feedback. As climate change leaves "gilded" coastal-development anthromes more exposed to extreme events, they could be more susceptible to collapse or conversion to alternative uses of coastal space. However, unsustainable as these systems may seem, some take the opposite perspective: that deep investments in mitigation and maintenance lend some developed coasts remarkable adaptive resilience, even in response to large disasters [160].

\subsection{Geoengineered Coasts}

Perhaps the opposite of historical legacy in a coastal environment is the effectively instantaneous creation of a new physical space, such as through land reclamation (e.g., ditching and draining) or related processes of made ground (e.g., armouring and back-filling). While Dubai has made artificial islands (Figure 1I) into a real-estate novelty, China is actively creating islands in the South China Sea [161]. Singapore increased its physical area by $130 \mathrm{~km}^{2}(\sim 20 \%)$ in 40 years, primarily by using aggregates to reclaim land [162]. Since the 1960s, major reaches of the present Dutch coast were either created or built out under the Deltaworks programme [163-165]. Not all land reclamation is so spectacular-it is also a common, cumulative consequence of historical agricultural land uses [166].

"Building with nature" and "ecological engineering" programmes are examining ways of using natural landscape dynamics to make vulnerable environments more resilient to extreme events and climate change [166-168]. For example, "managed realignment" sites deliberate breaches in seawalls to regenerate marshes in marginal coastal lowlands, offering both natural flood protection and habitat restoration [169]. Likewise, large-scale, coordinated interventions to deliberately route sediment to drowning deltaic areas can counteract marsh loss and improve storm-surge protection [170-172]. Large-scale sediment delivery is being proposed and trialled along nourished coastlines $[173,174]$, in part to reduce the total cost and amount of mechanical manipulation involved in standard nourishment practices. In the wake of Hurricane Sandy in 2012, strategies suggested for preventing future damage included deliberate reconstruction of oyster reefs in and around New York Harbor [175-178].

Even without megaprojects, collective and cumulative direct human manipulation of coastal geography occurs on a physical scale large enough to constitute a form of global geoengineering [113,179]. Seawalls may have proliferated in recent decades $[24,180]$, but they are an ancient technology [181,182]. Recurrent beach nourishment is nearly a century old [183], and analysis of long-term shoreline change rates suggests that towns along the US Mid-Atlantic collectively implement enough beach nourishment to obscure if not mask physical evidence of chronic coastal erosion [184]. Meanwhile, dams and levees obstruct sediment delivery to beaches [185], deltas [130,131,172], and coastal oceans [25]. As agents of geomorphic change, humans annually move more earth mass through agriculture, mining, housing starts, and highway construction than all geomorphic processes combined [20]. Wave action moves $\sim 1$ Gt of sediment around the planet annually $[20,179]$; countries with major beach nourishment programmes may introduce up to $\sim 10 \%$ of that natural total in equivalent annual beach fill $\left(\sim 67 \times 10^{6} \mathrm{~m}^{3} \cdot \mathrm{yr}^{-1}\right.$ beach fill (estimated in 2002) $\times \sim 1.5$ tonnes $\cdot \mathrm{m}^{-3}$ medium sand) [137]. In 2000, reported sand imports to Singapore alone $\left(\sim 170 \times 10^{6} \mathrm{~m}^{3}\right)$ [162] could have constituted a quarter of the total global flux from wave action.

Trends in coastal development (indeed, the long-term trajectory of human settlement in coastal environments [1]) is toward more rather than less constructed coastal geography [24,180,186], even if such geoengineering and ecological engineering is done in ways that include or mimic natural dynamics $[166,167,171,173]$. If all constructed coasts are anthromes, then perhaps the scales, types, and even the dynamics of the interventions that shape them [113] may inform their eventual classification.

\subsection{Challenges Make Opportunities}

The challenges inherent in defining coastal anthromes arguably sort into one of two categories. One involves the extent and resolution (spatial and temporal) of constituent data. Global datasets might include nested hierarchies of data spanning a range of spatial resolutions, but at their full extent 
they are coarse-grained by necessity, sacrificing detail for coverage. In the context of cumulative impact analysis (e.g., Figure 2), Halpern and Fujita [34] discuss approaches to "reconciling mismatches in resolution of overlapping datasets" (p. 6) and the compromises each approach entails; they remark that although the analytical method is not scale dependent, the utility of its results-such as for planning and management purposes-may be (i.e., small scales matter). The opportunity here is that this is an era of astounding growth in the coverage, resolution, availability, and quantitative analysis of geographic data. From the proliferation of low-cost, high-resolution satellites to the accelerating digitisation of historical archives, more data-and more diverse kinds of data-are becoming available all the time. If one critique of anthrome maps is that their classification is a static snapshot (based on a given imagery dataset or population census) of a dynamic system, then the number of available snapshots is surely growing, and their quality is improving: from snapshots, a flip-book-and quantifiable spatio-temporal changes.

Indeed, the second category of challenge pertains to dynamics-specifically, the challenge of representing dynamical human-environmental systems that are defined more by their functional space and metabolism than by the explicit extent of their spatial footprint [34,187]. However, geospatial time series, modelled and empirical, of global terrestrial anthromes [92,93] and marine cumulative impacts [4] are beginning to appear, along with a growing number of regional analyses [118,119,187-189]. The two primary categories of challenges to anthrome classification are thus related. Inroads into the static-data challenge make inroads into the dynamical-footprint challenge. By extension (and as others have argued before [34]), just because we might not be able to map a system in full-however "in full" may be defined, whether by coverage completeness or dynamical understanding or both-does not mean we should not attempt to map it at all. Thus, the overarching opportunity in pursuing novel maps of anthromic systems is what we might learn by generating them, and the new questions these visualisations might prompt.

\section{Conclusions}

While certain consequences of intervening in natural dynamics may be unintentional, the interventions themselves are not $[190,191]$. Anthromes are the result of both deliberate and accidental environmental change, of ecological destruction and opportunism [192]. Intention matters little in the context of defining areas of the planet as anthromes or wild biomes, but may have critical bearing in characterising and distinguishing one anthrome type from another. For example, penned aquaculture is an intentional conversion of coastal space and resources, and the link between effect (aquacultural products and by-products) and cause (the decision to farm-raise that product) is direct. By contrast, the emergence of an inshore lobster monoculture is unintentional and indirect-the effect (the gradual transformation of an inshore ecosystem) is a complex response to multiple interacting causes (cumulative decisions by fishers, governance of the fishery, ecological response to fishing pressures, and changes in gear technology).

Assuming that deliberate and accidental anthromes already characterise the planet's coasts, differentiating between them in space and time $[4,34]$ may lend insight into their internal dynamics, and their relationships (local and nonlocal) relative to each other [193]. Mapping and quantitatively describing coastal anthromes represents a research challenge closely related to the science of land change [194-197]. Issues of access, use, and governance long associated with terrestrial geography are rapidly extending to marine settings [26,32,33]. The utility of extending Ellis and Ramankutty's [18] framework for terrestrial anthromes-and likewise their hypotheses for testing anthromes as a more realistic model of the modern ecosphere-has itself crossed a threshold. In coastal and marine environments, future work is not in determining whether the concept of anthromes applies but rather in determining what exactly those anthromes are, where they exist, and how they manifest in specific settings.

Acknowledgments: I am grateful to Erle Ellis, Evan Goldstein, Patrick Limber, Alida Payson, and to several cohorts of Marine Geography undergraduates at Cardiff University, with whom many of these ideas took shape 
in syllabi and discussions. This work was supported in part by funding from Welsh Government and HEFCW through the Ser Cymru National Research Network for Low Carbon, Energy and the Environment RESILCOAST Project, and is a contribution to the UK NERC BLUEcoast project (NE/N015665/2). I also thank three anonymous reviewers for their constructive comments.

Conflicts of Interest: The author declares no conflict of interest.

\section{References}

1. Gillis, J.R. The Human Shore: Seacoasts in History; University of Chicago Press: Chicago, IL, USA, 2012.

2. Vitousek, P.M.; Mooney, H.A.; Lubchenco, J.; Melillo, J.M. Human domination of Earth's ecosystems. Science 1997, 277, 494-499. [CrossRef]

3. Halpern, B.S.; Walbridge, S.; Selkoe, K.A.; Kappel, C.V.; Micheli, F.; D'Agrosa, C.; Bruno, J.F.; Casey, K.S.; Ebert, C.; Fox, H.E.; et al. A global map of human impact on marine ecosystems. Science 2008, 319, $948-952$. [CrossRef] [PubMed]

4. Halpern, B.S.; Frazier, M.; Potapenko, J.; Casey, K.S.; Koenig, K.; Longo, C.; Lowndes, J.S.; Rockwood, R.C.; Selig, E.R.; Selkoe, K.A.; et al. Spatial and temporal changes in cumulative human impacts on the world's ocean. Nature Commun. 2015, 6, 7615. [CrossRef] [PubMed]

5. Wong, P.P.; Losada, I.J.; Gattuso, J.-P.; Hinkel, J.; Khattabi, A.; McInnes, K.L.; Saito, Y.; Sallenger, A. Coastal systems and low-lying areas. In Climate Change 2014: Impacts, Adaptation, and Vulnerability. Part A: Global and Sectoral Aspects. Contribution of Working Group II to the Fifth Assessment Report of the Intergovernmental Panel on Climate Change; Field, C.B., Barros, V.R., Dokken, D.J., Mach, K.J., Mastrandrea, M.D., Bilir, T.E., Chatterjee, M., Ebi, K.L., Estrada, Y.O., Genova, R.C., et al., Eds.; Cambridge University Press: Cambridge, UK; New York, NY, USA, 2014; pp. 361-409.

6. McCauley, D.J.; Pinsky, M.L.; Palumbi, S.R.; Estes, J.A.; Joyce, F.H.; Warner, R.R. Marine defaunation: Animal loss in the global ocean. Science 2015, 347, 247. [CrossRef] [PubMed]

7. WWF International. The Living Blue Planet Report 2015. Available online: http:/ /www.worldwildlife.org/ publications/living-blue-planet-report-2015 (accessed on 1 October 2016).

8. Erlandson, J.M. The archaeology of aquatic adaptations: Paradigms for a new millennium. J. Archaeol. Res. 2001, 9, 287-350. [CrossRef]

9. Erlandson, J.M.; Rick, T.C. Archeology meets marine historical ecology: the antiquity of maritime cultures and human impacts on marine fisheries and ecosystems. Annu. Rev. Mar. Sci. 2010, 2, 231-251. [CrossRef] [PubMed]

10. Marean, C.W.; Bar-Matthews, M.; Bernatchez, J.; Fisher, E.; Goldberg, P.; Herries, A.I.; Jacobs, Z.; Jerardino, A.; Karkanas, P.; Minichillo, T.; et al. Early human use of marine resources and pigment in South Africa during the Middle Pleistocene. Nature 2007, 449, 905-908. [CrossRef] [PubMed]

11. Macaulay, V.; Hill, C.; Achilli, A.; Rengo, C.; Clarke, D.; Meehan, W.; Blackburn, J.; Semino, O.; Scozzari, R.; Cruciani, F.; et al. Single, rapid coastal settlement of Asia revealed by analysis of complete mitochondrial genomes. Science 2005, 308, 1034-1036. [CrossRef] [PubMed]

12. O'Connor, S.; Ono, R.; Clarkson, C. Pelagic fishing at 42,000 years before the present and the maritime skills of modern humans. Science 2011, 334, 1117-1121. [CrossRef] [PubMed]

13. Fujita, M.; Yamasaki, S.; Katagiri, C.; Oshiro, I.; Sano, K.; Kurozumi, T.; Sugawara, H.; Kunikita, D.; Matsuzaki, H.; Kano, A.; et al. Advanced maritime adaptation in the western Pacific coastal region extends back to 35,000-30,000 years before present. Proc. Natl. Acad. Sci. USA 2016, 113, 11184-11189. [CrossRef] [PubMed]

14. Pedersen, M.W.; Ruter, A.; Schweger, C.; Friebe, H.; Staff, R.A.; Kjeldsen, K.K.; Mendoza, M.L.; Beaudoin, A.B.; Zutter, C.; Larsen, N.K.; et al. Postglacial viability and colonization in North America's ice-free corridor. Nature 2016, 537, 45-49. [CrossRef] [PubMed]

15. Fagan, B.M. The Long Summer: How Climate Changed Civilization; Basic Books: New York, NY, USA, 2004.

16. Ziegler, M.; Simon, M.H.; Hall, I.R.; Barker, S.; Stringer, C.; Zahn, R. Development of Middle Stone Age innovation linked to rapid climate change. Nature Commun. 2013, 4, 1905. [CrossRef] [PubMed]

17. O'Connell, J.F.; Allen, J. The process, biotic impact, and global implications of the human colonization of Sahul about 47,000 years ago. J. Archaeol. Sci. 2015, 56, 73-84. [CrossRef]

18. Ellis, E.C.; Ramankutty, N. Putting people in the map: Anthropogenic biomes of the world. Front. Ecol. Environ. 2008, 6, 439-447. [CrossRef] 
19. Ellis, E.C. Anthropogenic transformation of the terrestrial biosphere. Philos. T. Roy. Soc. A 2011, 369, 1010-1035. [CrossRef] [PubMed]

20. Hooke, R.L. On the efficacy of humans as geomorphic agents. GSA Today 1994, 4, 217, $224-225$.

21. Crutzen, P.J. Geology of mankind. Nature 2002, 415, 23. [CrossRef] [PubMed]

22. Steffen, W.; Grinevald, J.; Crutzen, P.; McNeill, J. The Anthropocene: Conceptual and historical perspectives. Philos. T. Roy. Soc. A 2011, 369, 842-867. [CrossRef] [PubMed]

23. Halpern, B.S.; Selkoe, K.A.; Micheli, F.; Kappel, C.V. Evaluating and ranking the vulnerability of global marine ecosystems to anthropogenic threats. Conserv. Biol. 2007, 21, 1301-1315. [CrossRef] [PubMed]

24. Nordstrom, K.F. Beaches and Dunes of Developed Coasts; Cambridge University Press: Cambridge, UK; New York, NY, USA, 2000.

25. Syvitski, J.P.; Vörösmarty, C.J.; Kettner, A.J.; Green, P. Impact of humans on the flux of terrestrial sediment to the global coastal ocean. Science 2005, 308, 376-380. [CrossRef] [PubMed]

26. Halpern, B.S.; Ebert, C.M.; Kappel, C.V.; Madin, E.M.P.; Micheli, F.; Perry, M.; Selkoe, K.A.; Walbridge, S. Global priority areas for incorporating land-sea connections in marine conservation. Conserv. Lett. 2009, 2, 189-196. [CrossRef]

27. Lazarus, E.D.; Ellis, M.A.; Murray, A.B.; Hall, D.M. An evolving research agenda for human-coastal systems. Geomorphology 2016, 256, 81-90. [CrossRef]

28. Jackson, J.B.C.; Kirby, M.X.; Berger, W.H.; Bjorndal, K.A.; Botsford, L.W.; Bourque, B.J.; Bradbury, R.H.; Cooke, R.; Erlandson, J.; Estes, J.A.; et al. Historical overfishing and the recent collapse of coastal ecosystems. Science 2001, 293, 629-637. [CrossRef] [PubMed]

29. Pauly, D.; Christensen, V.; Guénette, S.; Pitcher, T.J.; Sumaila, U.R.; Walters, C.J.; Watson, R.; Zeller, D. Towards sustainability in world fisheries. Nature 2002, 418, 689-695. [CrossRef] [PubMed]

30. Pusceddu, A.; Bianchelli, S.; Martín, J.; Puig, P.; Palanques, A.; Masqué, P.; Danovaro, R. Chronic and intensive bottom trawling impairs deep-sea biodiversity and ecosystem functioning. Proc. Natl. Acad. Sci. USA 2014, 111, 8861-8866. [CrossRef] [PubMed]

31. Adger, W.N. Social and ecological resilience: are they related? Prog. Hum. Geog. 2000, 24, 347-364. [CrossRef]

32. Steinberg, P.E. Navigating to multiple horizons: Toward a geography of ocean-space. Prof. Geogr. 1999, 51, 366-375. [CrossRef]

33. Steinberg, P.E. The Social Construction of the Ocean; Cambridge University Press: Cambridge, UK, 2001.

34. Halpern, B.S.; Fujita, R. Assumptions, challenges, and future directions in cumulative impact analysis. Ecosphere 2013, 4, 1-11. [CrossRef]

35. Haff, P.K. Hillslopes, rivers, plows, and trucks: Mass transport on Earth's surface by natural and technological processes. Earth Surf. Proc. Land. 2010, 35, 1157-1166. [CrossRef]

36. Jackson, J.B.C. Ecological extinction and evolution in the brave new ocean. Proc. Natl. Acad. Sci. USA 2008, 105 (Supp. 1), 11458-11465. [CrossRef] [PubMed]

37. Jackson, J.B.C. The future of the oceans past. Philos. T. Roy. Soc. B 2010, 365, 3765-3778. [CrossRef] [PubMed]

38. Doney, S.C. The growing human footprint on coastal and open-ocean biogeochemistry. Science 2010, 328, 1512-1516. [CrossRef] [PubMed]

39. Vörösmarty, C.J.; McIntyre, P.B.; Gessner, M.O.; Dudgeon, D.; Prusevich, A.; Green, P.; Glidden, S.; Bunn, S.E.; Sullivan, C.A.; Liermann, C.R.; et al. Global threats to human water security and river biodiversity. Nature 2010, 467, 555-561. [CrossRef] [PubMed]

40. Diaz, R.J.; Rosenberg, R. Spreading dead zones and consequences for marine ecosystems. Science 2008, 321, 926-929. [CrossRef] [PubMed]

41. Jenny, J.-P.; Francus, P.; Normandeau, A.; Lapointe, F.; Perga, M.-E.; Ojala, A.; Schimmeimann, A.; Zolitschka, B. Global spread of hypoxia in freshwater ecosystems during the last three centuries is caused by rising local human pressure. Glob. Change Biol. 2016, 22, 1481-1489. [CrossRef] [PubMed]

42. Rabalais, N.N.; Cai, W.-J.; Carstensen, J.; Conley, D.J.; Fry, B.; Hu, X.; Quinones-Rivera, Z.; Rosenberg, R.; Slomp, C.P.; Turner, R.E.; et al. Eutrophication-driven deoxygenation in the coastal ocean. Oceanography 2014, 27, 172-183. [CrossRef]

43. Sawyer, A.H.; David, C.H.; Famiglietti, J.S. Continental patterns of submarine groundwater discharge reveal coastal vulnerabilities. Science 2016, 353, 705-707. [CrossRef] [PubMed]

44. Pauly, D.; Christensen, V. Primary production required to sustain global fisheries. Nature 1995, 374, $255-257$. [CrossRef] 
45. Watling, L.; Norse, E.A. Disturbance of the seabed by mobile fishing gear: A comparison to forest clearcutting. Conserv. Biol. 1998, 12, 1180-1197. [CrossRef]

46. Pelling, M.; Blackburn, S. Megacities and the Coast: Risk, Resilience and Transformation; Routledge: London, UK; New York, NY, USA, 2014.

47. Valiela, I.; Bowen, J.L.; York, J.K. Mangrove forests: One of the world's threatened major tropical environments. BioScience 2001, 51, 807-815. [CrossRef]

48. Polidoro, B.A.; Carpenter, K.E.; Collins, L.; Duke, N.C.; Ellison, A.M.; Ellison, J.C.; Farnsworth, E.J.; Fernando, E.S.; Kathiresan, K.; Koedam, N.E.; et al. The loss of species: Mangrove extinction risk and geographic areas of global concern. PLoS ONE 2010, 5, e10095. [CrossRef] [PubMed]

49. Giri, C.; Ochieng, E.; Tieszen, L.L.; Zhu, Z.; Singh, A.; Loveland, T.; Masek, J.; Duke, N. Status and distribution of mangrove forests of the world using earth observation satellite data. Global Ecol. Biogeogr. 2011, 20, 154-159. [CrossRef]

50. Orth, R.J.; Carruthers, T.J.; Dennison, W.C.; Duarte, C.M.; Fourqurean, J.W.; Heck, K.L.; Hughes, A.R.; Kendrick, G.A.; Kenworthy, W.J.; Olyarnik, S.; et al. A global crisis for seagrass ecosystems. BioScience 2006, 56, 987-996. [CrossRef]

51. Waycott, M.; Duarte, C.M.; Carruthers, T.J.; Orth, R.J.; Dennison, W.C.; Olyarnik, S.; Calladine, A.; Fourqurean, J.W.; Heck, K.L.; Hughes, A.R.; et al. Accelerating loss of seagrasses across the globe threatens coastal ecosystems. Proc. Natl. Acad. Sci. USA 2009, 106, 12377-12381. [CrossRef] [PubMed]

52. Gedan, K.B.; Silliman, B.R.; Bertness, M.D. Centuries of human-driven change in salt marsh ecosystems. Annu. Rev. Mar. Sci. 2009, 1, 117-141. [CrossRef] [PubMed]

53. Kirwan, M.L.; Megonigal, J.P. Tidal wetland stability in the face of human impacts and sea-level rise. Nature 2013, 504, 53-60. [CrossRef] [PubMed]

54. Lotze, H.K.; Lenihan, H.S.; Bourque, B.J.; Bradbury, R.H.; Cooke, R.G.; Kay, M.C.; Kidwell, S.M.; Kirby, M.X.; Peterson, C.H.; Jackson, J.B.C. Depletion, degradation, and recovery potential of estuaries and coastal seas. Science 2006, 312, 1806-1809. [CrossRef] [PubMed]

55. Kirby, M.X. Fishing down the coast: historical expansion and collapse of oyster fisheries along continental margins. Proc. Natl. Acad. Sci. USA 2004, 101, 13096-13099. [CrossRef] [PubMed]

56. Pandolfi, J.M.; Bradbury, R.H.; Sala, E.; Hughes, T.P.; Bjorndal, K.A.; Cooke, R.G.; McArdle, D.; McClenachan, L.; Newman, M.J.; Paredes, G.; et al. Global trajectories of the long-term decline of coral reef ecosystems. Science 2003, 301, 955-958. [CrossRef] [PubMed]

57. Bellwood, D.R.; Hughes, T.P.; Folke, C.; Nyström, M. Confronting the coral reef crisis. Nature 2004, 429, 827-833. [CrossRef] [PubMed]

58. Steneck, R.S.; Graham, M.H.; Bourque, B.J.; Corbett, D.; Erlandson, J.M.; Estes, J.A.; Tegner, M.J. Kelp forest ecosystems: Biodiversity, stability, resilience and future. Environ. Conserv. 2002, 29, 436-459. [CrossRef]

59. Nordstrom, K.F. Beaches and dunes of human-altered coasts. Prog. Phys. Geog. 1994, 18, 497-516. [CrossRef]

60. Jackson, J.B.C. What was natural in the coastal oceans? Proc. Natl. Acad. Sci. USA 2001, 98, 5411-5418. [CrossRef] [PubMed]

61. Goodall, D.W. (Ed.) Ecosystems of the World; Elsevier: Amsterdam, The Netherlands, 1974-; Volume 38.

62. Olson, D.M.; Dinerstein, E.; Wikramanayake, E.D.; Burgess, N.D.; Powell, G.V.; Underwood, E.C.; D'amico, J.A.; Itoua, I.; Strand, H.E.; Morrison, J.C.; et al. Terrestrial ecoregions of the world: A new map of life on Earth. BioScience 2001, 51, 933-938. [CrossRef]

63. Smith, H.D. The development and management of the world ocean. Ocean Coast. Manage. 1994, $24,3-16$. [CrossRef]

64. Smith, H.D. The industrialisation of the world ocean. Ocean Coast. Manage. 2000, 43, 11-28. [CrossRef]

65. Douvere, F. The importance of marine spatial planning in advancing ecosystem-based sea use management. Mar. Policy 2008, 32, 762-771. [CrossRef]

66. Martin, K.S.; Hall-Arber, M. The missing layer: Geo-technologies, communities, and implications for marine spatial planning. Mar. Policy 2008, 32, 779-786. [CrossRef]

67. Foley, M.M.; Halpern, B.S.; Micheli, F.; Armsby, M.H.; Caldwell, M.R.; Crain, C.M.; Prahler, E.; Rohr, N.; Sivas, D.; Beck, M.W.; et al. Guiding ecological principles for marine spatial planning. Mar. Policy 2010, 34, 955-966. [CrossRef]

68. Paine, L. The Sea and Civilization: A Maritime History of the World; Atlantic Books Ltd.: London, UK, 2014. 
69. McGranahan, G.; Balk, D.; Anderson, B. The rising tide: Assessing the risks of climate change and human settlements in low elevation coastal zones. Environ. Urban. 2007, 19, 17-37. [CrossRef]

70. Olson, D.M.; Dinerstein, E. The Global 200: A representation approach to conserving the Earth's most biologically valuable ecoregions. Conserv. Biol. 1998, 12, 502-515. [CrossRef]

71. Doody, J.P. Coastal Conservation and Management; Springer: London, UK, 2001.

72. Bakker, J.P. The impact of grazing on plant communities, plant populations and soil conditions on salt marshes. Vegetatio 1985, 62, 391-398. [CrossRef]

73. Kiehl, K.; Eischeid, I.; Gettner, S.; Walter, J. Impact of different sheep grazing intensities on salt marsh vegetation in northern Germany. J. Veg. Sci. 1996, 7, 99-106. [CrossRef]

74. Blanco-Libreros, J.F.; Estrada-Urrea, E.A. Mangroves on the edge: Anthrome-dependent fragmentation influences ecological condition (Turbo, Colombia, Southern Caribbean). Diversity 2015, 7, 206-228. [CrossRef]

75. Vafeidis, A.T.; Nicholls, R.J.; McFadden, L.; Tol, R.S.; Hinkel, J.; Spencer, T.; Grashoff, P.S.; Boot, G.; Klein, R.J. A new global coastal database for impact and vulnerability analysis to sea-level rise. J. Coastal Res. 2008, 24, 917-924. [CrossRef]

76. Folke, C.; Kautsky, N. Aquaculture with its environment: Prospects for sustainability. Ocean Coast. Manage. 1992, 17, 5-24. [CrossRef]

77. Newkirk, G. Sustainable coastal production systems: A model for integrating aquaculture and fisheries under community management. Ocean Coast. Manage. 1996, 32, 69-83. [CrossRef]

78. Brzeski, V.; Newkirk, G. Integrated coastal food production systems-A review of current literature. Ocean Coast. Manage. 1997, 34, 55-71. [CrossRef]

79. Troell, M.; Kautsky, N.; Folke, C. Applicability of integrated coastal aquaculture systems. Ocean Coast. Manage. 1999, 42, 63-70.

80. Chopin, T.; Buschmann, A.H.; Halling, C.; Troell, M.; Kautsky, N.; Neori, A.; Kraemer, G.P.; Zertuche-González, J.A.; Yarish, C.; Neefus, C. Integrating seaweeds into marine aquaculture systems: A key toward sustainability. J. Phycol. 2001, 37, 975-986. [CrossRef]

81. Warnock, N.; Page, G.W.; Ruhlen, T.D.; Nur, N.; Takekawa, J.Y.; Hanson, J.T. Management and conservation of San Francisco Bay salt ponds: Effects of pond salinity, area, tide, and season on Pacific Flyway waterbirds. Waterbirds 2002, 25, 79-92.

82. Brown, B.; Wilson, W.H. The role of commercial digging of mudflats as an agent for change of infaunal intertidal populations. J. Exp. Mar. Biol. Ecol. 1997, 218, 49-61. [CrossRef]

83. Mouritsen, O.G.; Mouritsen, J.D.; Johansen, M. Seaweeds: Edible, Available, and Sustainable; University of Chicago Press: Chicago, IL, USA, 2013.

84. Dalton, R. Aquaculture: Fishing for trouble. Nature 2004, 431, 502-504. [CrossRef] [PubMed]

85. Stergiou, K.I.; Tsikliras, A.C.; Pauly, D. Farming up Mediterranean food webs. Conserv. Biol. 2009, 23, $230-232$. [CrossRef] [PubMed]

86. Steneck, R.S.; Hughes, T.P.; Cinner, J.E.; Adger, W.N.; Arnold, S.N.; Berkes, F.; Boudreau, S.A.; Brown, K.; Folke, C.; Gunderson, L.; et al. Creation of a gilded trap by the high economic value of the Maine lobster fishery. Conserv. Biol. 2011, 25, 904-912. [CrossRef] [PubMed]

87. Puig, P.; Canals, M.; Company, J.B.; Martín, J.; Amblas, D.; Lastras, G.; Palanques, A.; Calafat, A.M. Ploughing the deep sea floor. Nature 2012, 489, 286-289. [CrossRef] [PubMed]

88. Petersen, J.K.; Malm, T. Offshore windmill farms: Threats to or possibilities for the marine environment. Ambio 2006, 35, 75-80. [CrossRef]

89. Quigel, J.C.; Thornton, W.L. Rigs to reefs-A case history. B. Mar. Sci. 1989, 44, 799-806.

90. Spalding, M.D.; Fox, H.E.; Allen, G.R.; Davidson, N.; Ferdaña, Z.A.; Finlayson, M.A.X.; Halpern, B.S.; Jorge, M.A.; Lombana, A.L.; Lourie, S.A.; et al. Marine ecoregions of the world: A bioregionalization of coastal and shelf areas. BioScience 2007, 57, 573-583. [CrossRef]

91. Halpern, B.S.; McLeod, K.L.; Rosenberg, A.A.; Crowder, L.B. Managing for cumulative impacts in ecosystem-based management through ocean zoning. Ocean Coast. Manage. 2008, 51, 203-211. [CrossRef]

92. Ellis, E.C.; Klein Goldewijk, K.; Siebert, S.; Lightman, D.; Ramankutty, N. Anthropogenic transformation of the biomes, 1700 to 2000. Glob. Ecol. Biogeogr. 2010, 19, 589-606. [CrossRef]

93. Ellis, E.C.; Kaplan, J.O.; Fuller, D.Q.; Vavrus, S.; Goldewijk, K.K.; Verburg, P.H. Used planet: A global history. Proc. Natl. Acad. Sci. USA 2013, 110, 7978-7985. [CrossRef] [PubMed] 
94. International Comprehensive Ocean-Atmosphere Data Set (ICOADS). US Maury collection (ship's names and voyages, 1784-1863). Available online: http:/ /icoads.noaa.gov/maury.html (accessed on 1 October 2016).

95. Ames, E.P. Atlantic cod stock structure in the Gulf of Maine. Fisheries 2004, 29, 10-28. [CrossRef]

96. Smith, T.M.; Reynolds, R.W.; Peterson, T.C.; Lawrimore, J. Improvements to NOAA's historical merged land-ocean surface temperature analysis (1880-2006). J. Climate 2008, 21, 2283-2296. [CrossRef]

97. Pinsky, M.L.; Jensen, O.P.; Ricard, D.; Palumbi, S.R. Unexpected patterns of fisheries collapse in the world's oceans. Proc. Natl. Acad. Sci. USA 2011, 108, 8317-8322. [CrossRef] [PubMed]

98. Airoldi, L.; Beck, M.W. Loss, status and trends for coastal marine habitats of Europe. Oceanogr. Mar. Biol. 2007, 45, 345-405.

99. McLean, J.H. Sublittoral ecology of kelp beds of the open coast area near Carmel, California. Biol. Bull. 1962, 122, 95-114. [CrossRef]

100. Dayton, P.K.; Tegner, M.J.; Edwards, P.B.; Riser, K.L. Sliding baselines, ghosts, and reduced expectations in kelp forest communities. Ecol. Appl. 1998, 8, 309-322. [CrossRef]

101. Lebel, L.; Anderies, J.M.; Campbell, B.; Folke, C.; Hatfield-Dodds, S.; Hughes, T.P.; Wilson, J. Governance and the capacity to manage resilience in regional social-ecological systems. Ecol. Soc. 2006, 11, 19. [CrossRef]

102. Foster, D.; Aber, J.; Cogbill, C.; Hart, C.; Colburn, E.; D’Amato, A.; Donahue, B.; Driscoll, C.; Ellison, A.; Fahey, T.; et al. Wildlands and Woodlands: A Vision for the New England Landscape; Harvard University Press: Cambridge, MA, USA, 2010; Available online: http:/ /harvardforest.fas.harvard.edu/other-tags/wildlandswoodlands (accessed on 1 October 2016).

103. Kirwan, M.L.; Murray, A.B.; Donnelly, J.P.; Corbett, D.R. Rapid wetland expansion during European settlement and its implication for marsh survival under modern sediment delivery rates. Geology 2011, 39, 507-510. [CrossRef]

104. Barbier, E.B.; Hacker, S.D.; Kennedy, C.; Koch, E.W.; Stier, A.C.; Silliman, B.R. The value of estuarine and coastal ecosystem services. Ecol. Monogr. 2011, 81, 169-193. [CrossRef]

105. Loarie, S.R.; Duffy, P.B.; Hamilton, H.; Asner, G.P.; Field, C.B.; Ackerly, D.D. The velocity of climate change. Nature 2009, 462, 1052-1055. [CrossRef] [PubMed]

106. Neilson, R.P. Transient ecotone response to climatic change: some conceptual and modeling approaches. Ecol. Appl. 1993, 3, 385-395. [CrossRef] [PubMed]

107. Lloyd, K.M.; McQueen, A.A.M.; Lee, B.J.; Wilson, R.C.B.; Walker, S.; Wilson, J.B. Evidence on ecotone concepts from switch, environmental and anthropogenic ecotones. J. Veg. Sci. 2000, 11, 903-910. [CrossRef]

108. Pinsky, M.L.; Worm, B.; Fogarty, M.J.; Sarmiento, J.L.; Levin, S.A. Marine taxa track local climate velocities. Science 2013, 341, 1239-1242. [CrossRef] [PubMed]

109. Lazarus, E.D.; McGill, B.J. Pushing the pace of tree species migration. PLoS ONE 2014, 9, e105380. [CrossRef] [PubMed]

110. Pinsky, M.L.; Fogarty, M. Lagged social-ecological responses to climate and range shifts in fisheries. Climatic Change 2012, 115, 883-891. [CrossRef]

111. Myers, N. Environmental refugees: A growing phenomenon of the 21st century. Philos. T. Roy. Soc. B 2002, 357, 609-613. [CrossRef] [PubMed]

112. Hundley, N. Water and the West: the Colorado River Compact and the Politics of Water in the American West; University of California Press: Berkeley, CA, USA, 2009.

113. Lazarus, E.D. Threshold effects of hazard mitigation in coastal human-environmental systems. Earth Surf. Dynam. 2014, 2, 35-45. [CrossRef]

114. Holland, J. Emergence: From Chaos to Order; Basic Books: New York, NY, USA, 1998.

115. Werner, B.T.; Mcnamara, D.E. Dynamics of coupled human-landscape systems. Geomorphology 2007, 91, 393-407. [CrossRef]

116. Marsh, G.P. Man and Nature, or Physical Geography as Modified by Human Action; Scribner: New York, NY, USA, 1869.

117. Marsh, G.P. The Earth as Modified by Human Action; Scribner: New York, NY, USA, 1882.

118. Turner, B.L.; Matson, P.A.; McCarthy, J.J.; Corell, R.W.; Christensen, L.; Eckley, N.; Hovelsrud-Broda, G.K.; Kasperson, J.X.; Kasperson, R.E.; Luers, A.; et al. Illustrating the coupled human-environment system for vulnerability analysis: three case studies. Proc. Natl. Acad. Sci. USA 2003, 100, 8080-8085. [CrossRef] [PubMed] 
119. Liu, J.; Dietz, T.; Carpenter, S.R.; Alberti, M.; Folke, C.; Moran, E.; Pell, A.N.; Deadman, P.; Kratz, T.; Lubchenco, J.; et al. Complexity of coupled human and natural systems. Science 2007, 317, 1513-1516. [CrossRef] [PubMed]

120. Scheffer, M. Critical Transitions in Nature and Society; Princeton University Press: Princeton, NJ, USA, 2009.

121. Ostrom, E. A general framework for analyzing sustainability of social-ecological systems. Science 2009, 325, 419-422. [CrossRef] [PubMed]

122. Di Baldassarre, G.; Viglione, A.; Carr, G.; Kuil, L.; Salinas, J.L.; Blöschl, G. Socio-hydrology: conceptualising human-flood interactions. Hydrol. Earth Syst. Sci. 2013, 17, 3295-3303. [CrossRef]

123. Wilson, J.; Yan, L.; Wilson, C. The precursors of governance in the Maine lobster fishery. Proc. Natl. Acad. Sci. USA 2007, 104, 15212-15217. [CrossRef] [PubMed]

124. Jury, S.H.; Howell, H.; O'Grady, D.F.; Watson, W.H., III. Lobster trap video: in situ video surveillance of the behaviour of Homarus americanus in and around traps. Mar. Freshwater Res. 2001, 52, 1125-1132. [CrossRef]

125. Hutchings, J.A. Collapse and recovery of marine fishes. Nature 2000, 406, 882-885. [CrossRef] [PubMed]

126. Dugmore, A.J.; McGovern, T.H.; Vésteinsson, O.; Arneborg, J.; Streeter, R.; Keller, C. Cultural adaptation, compounding vulnerabilities and conjunctures in Norse Greenland. Proc. Natl. Acad. Sci. USA 2012, 109, 3658-3663. [CrossRef] [PubMed]

127. Young, N.E.; Schweinsberg, A.D.; Briner, J.P.; Schaefer, J.M. Glacier maxima in Baffin Bay during the Medieval Warm Period coeval with Norse settlement. Sci. Adv. 2015, 1, e1500806. [CrossRef] [PubMed]

128. Boonstra, W.J.; de Boer, F.W. The historical dynamics of social-ecological traps. Ambio 2014, 43, $260-274$. [CrossRef] [PubMed]

129. Criss, R.E.; Shock, E.L. Flood enhancement through flood control. Geology 2001, 29, 875-878. [CrossRef]

130. Syvitski, J.P.; Kettner, A.J.; Overeem, I.; Hutton, E.W.; Hannon, M.T.; Brakenridge, G.R.; Day, J.; Vörösmarty, C.; Saito, Y.; Giosan, L.; et al. Sinking deltas due to human activities. Nature Geosci. 2009, 2, 681-686. [CrossRef]

131. Syvitski, J.P. Deltas at risk. Sustain. Sci. 2008, 3, 23-32. [CrossRef]

132. McNamara, D.E.; Keeler, A. A coupled physical and economic model of the response of coastal real estate to climate risk. Nat. Clim. Change 2013, 3, 559-562. [CrossRef]

133. McNamara, D.E.; Murray, A.B.; Smith, M.D. Coastal sustainability depends on how economic and coastline responses to climate change affect each other. Geophys. Res. Lett. 2011, 38, L07401. [CrossRef]

134. Ells, K.; Murray, A.B. Long-term, non-local coastline responses to local shoreline stabilization. Geophys. Res. Lett. 2012, 39, L19401. [CrossRef]

135. Rogers, L.J.; Moore, L.J.; Goldstein, E.B.; Hein, C.J.; Lorenzo-Trueba, J.; Ashton, A.D. Anthropogenic controls on overwash deposition: Evidence and consequences. J. Geophys. Res. Earth 2015, 120, 2609-2624. [CrossRef]

136. National Research Council (NRC). Reducing Coastal Risk on the East and Gulf Coasts; National Academies Press: Washington, DC, USA, 2014.

137. Hanson, H.; Brampton, A.; Capobianco, M.; Dette, H.H.; Hamm, L.; Laustrup, C.; Lechuga, A.; Spanhoff, R. Beach nourishment projects, practices, and objectives-A European overview. Coast. Eng. 2002, 47, 81-111. [CrossRef]

138. NRC. Beach Nourishment and Protection; National Academies Press: Washington, DC, USA, 1995.

139. Lazarus, E.D.; McNamara, D.E.; Smith, M.D.; Gopalakrishnan, S.; Murray, A.B. Emergent behavior in a coupled economic and coastline model for beach nourishment. Nonlin. Process. Geophys. 2011, 18, 989-999. [CrossRef]

140. Nordstrom, K. Beach nourishment and coastal habitats: Research needs to improve compatibility. Restor. Ecol. 2005, 13, 215-222. [CrossRef]

141. Peterson, C.H.; Bishop, M.J. Assessing the environmental impacts of beach nourishment. BioScience 2005, 55, 887-896. [CrossRef]

142. Peterson, C.H.; Bishop, M.J.; Johnson, G.A.; D'Anna, L.M.; Manning, L.M. Exploiting beach filling as an unaffordable experiment: benthic intertidal impacts propagating upwards to shorebirds. J. Exp. Mar. Biol. Ecol. 2006, 338, 205-221. [CrossRef]

143. Speybroeck, J.; Bonte, D.; Courtens, W.; Gheskiere, T.; Grootaert, P.; Maelfait, J.P.; Mathys, M.; Provoost, S.; Sabbe, K.; Stienen, E.W.; et al. Beach nourishment: an ecologically sound coastal defence alternative? A review. Aquat. Conserv. 2006, 16, 419-435. [CrossRef] 
144. Grain, D.A.; Bolten, A.B.; Bjorndal, K.A. Effects of beach nourishment on sea turtles: review and research initiatives. Restor. Ecol. 1995, 3, 95-104. [CrossRef]

145. Hays, G.C.; Ashworth, J.S.; Barnsley, M.J.; Broderick, A.C.; Emery, D.R.; Godley, B.J.; Henwood, A.; Jones, E.L. The importance of sand albedo for the thermal conditions on sea turtle nesting beaches. Oikos 2001, 93, 87-94. [CrossRef]

146. Steinitz, M.J.; Salmon, M.; Wyneken, J. Beach renourishment and loggerhead turtle reproduction: A seven year study at Jupiter Island, Florida. J. Coastal Res. 1998, 14, 1000-1013.

147. Grootjans, A.P.; Geelen, H.W.T.; Jansen, A.J.M.; Lammerts, E.J. Restoration of coastal dune slacks in the Netherlands. Hydrobiologia 2002, 478, 181-203. [CrossRef]

148. Nordstrom, K.F.; Jackson, N.L.; Bruno, M.S.; de Butts, H.A. Municipal initiatives for managing dunes in coastal residential areas: a case study of Avalon, New Jersey, USA. Geomorphology 2002, 47, 137-152. [CrossRef]

149. Goldstein, E.B.; Moore, L.J. Stability and bistability in a one-dimensional model of coastal foredune height. J. Geophys. Res. Earth Surf. 2016, 121, 964-977. [CrossRef]

150. Walters, D.C.; Kirwan, M.L. Optimal hurricane overwash thickness for maximizing marsh resilience to sea level rise. Ecol. Evol. 2016, 6, 2948-2956.

151. Schupp, C.A.; Winn, N.T.; Pearl, T.L.; Kumer, J.P.; Carruthers, T.J.; Zimmerman, C.S. Restoration of overwash processes creates piping plover (Charadrius melodus) habitat on a barrier island (Assateague Island, Maryland). Estuar. Coast. Shelf S. 2013, 116, 11-20. [CrossRef]

152. Smith, M.D.; Slott, J.M.; McNamara, D.; Murray, A.B. Beach nourishment as a dynamic capital accumulation problem. J. Environ. Econ. Manag. 2009, 58, 58-71. [CrossRef]

153. Gopalakrishnan, S.; Smith, M.D.; Slott, J.M.; Murray, A.B. The value of disappearing beaches: a hedonic pricing model with endogenous beach width. J. Environ. Econ. Manag. 2011, 61, 297-310. [CrossRef]

154. Mileti, D. Disasters by Design: A Reassessment of Natural Hazards in the United States; Joseph Henry Press: Washington, DC, USA, 1999.

155. Armstrong, S.B.; Lazarus, E.D.; Limber, P.W.; Goldstein, E.B.; Thorpe, C.; Ballinger, R.C. Indications of a positive feedback between coastal development and beach nourishment. Earth's Future 2016, 4, 626-635. [CrossRef]

156. Krippendorf, J. Ecological approach to tourism marketing. Tourism Manage. 1987, 8, 174-176. [CrossRef]

157. McCool, S.F.; Moisey, R.N. (Eds.) Tourism, Recreation and Sustainability: Linking Culture and the Environment, 2nd ed.; CAB International: Oxford, UK; New York, NY, USA, 2008.

158. Tao, T.C.; Wall, G. Tourism as a sustainable livelihood strategy. Tourism Manage. 2009, 30, 90-98. [CrossRef]

159. Cooper, J.A.G.; McKenna, J. Boom and bust: the influence of macroscale economics on the world's coasts. J. Coastal Res. 2009, 253, 533-538. [CrossRef]

160. Adger, W.N.; Hughes, T.P.; Folke, C.; Carpenter, S.R.; Rockström, J. Social-ecological resilience to coastal disasters. Science 2005, 309, 1036-1039. [CrossRef] [PubMed]

161. Watkins, D. What China has been building in the South China Sea. New York Times. 27 October 2015. Available online: http:/ / www.nytimes.com/interactive/2015/07/30/world/asia/what-china-has-beenbuilding-in-the-south-china-sea.html?_r=0 (accessed on 1 October 2016).

162. United Nations Environment Programme (UNEP). Sand, rarer than one thinks. Available online: http://www.unep.org/pdf/UNEP_GEAS_March_2014.pdf (accessed on 1 October 2016).

163. Dutch Delta Commission. Available online: http://www.deltacommissie.com/ (accessed on 1 October 2016).

164. Kabat, P.; van Vierssen, W.; Veraart, J.; Vellinga, P.; Aerts, J. Climate proofing the Netherlands. Nature 2005, 438, 283-284. [CrossRef] [PubMed]

165. Kabat, P.; Fresco, L.O.; Stive, M.J.F.; Veerman, C.P.; van Alphen, J.S.V.L.; Parmet, B.W.A.H.; Hazeleger, W.; Katsman, C.A. Dutch coasts in transition. Nature Geosci. 2009, 2, 450-452. [CrossRef]

166. Temmerman, S.; Meire, P.; Bouma, T.J.; Herman, P.M.; Ysebaert, T.; de Vriend, H.J. Ecosystem-based coastal defence in the face of global change. Nature 2013, 504, 79-83. [CrossRef] [PubMed]

167. Cheong, S.M.; Silliman, B.; Wong, P.P.; van Wesenbeeck, B.; Kim, C.K.; Guannel, G. Coastal adaptation with ecological engineering. Nature Clim. Change 2013, 3, 787-791. [CrossRef]

168. Van Slobbe, E.; de Vriend, H.J.; Aarninkhof, S.; Lulofs, K.; de Vries, M.; Dircke, P. Building with nature: In search of resilient storm surge protection strategies. Nature Hazards 2013, 65, 947-966. [CrossRef] 
169. French, P.W. Managed realignment-the developing story of a comparatively new approach to soft engineering. Estuar. Coast. Shelf S. 2006, 67, 409-423. [CrossRef]

170. Louisiana Coastal Protection and Restoration Authority. Louisiana's Comprehensive Master Plan for a Stainable Coast; CPRA: Baton Rouge, LA, USA, 2012. Available online: http://coastal.la.gov/a-common-vision/2012coastal-master-plan/ (accessed on 1 October 2016).

171. Paola, C.; Twilley, R.R.; Edmonds, D.A.; Kim, W.; Mohrig, D.; Parker, G.; Viparelli, E.; Voller, V.R. Natural processes in delta restoration: application to the Mississippi Delta. Ann. Rev. Mar. Sci. 2011, 3, 67-91. [CrossRef] [PubMed]

172. Giosan, L.; Syvitski, J.; Constantinescu, S.; Day, J. Climate change: Protect the world's deltas. Nature 2014, 516, 31-33. [CrossRef] [PubMed]

173. Stive, M.J.; de Schipper, M.A.; Luijendijk, A.P.; Aarninkhof, S.G.; van Gelder-Maas, C.; van Thiel de Vries, J.S.; de Vries, S.; Henriquez, M.; Marx, S.; Ranasinghe, R. A new alternative to saving our beaches from sea-level rise: The sand engine. J. Coastal Res. 2013, 29, 1001-1008. [CrossRef]

174. Brown, J.M.; Phelps, J.J.; Barkwith, A.; Hurst, M.D.; Ellis, M.A.; Plater, A.J. The effectiveness of beach mega-nourishment, assessed over three management epochs. J. Environ. Manage. 2016, 184, 400-408. [CrossRef] [PubMed]

175. Tollefson, J. Hurricane sweeps into climate-adaptation debate. Nature 2012, 491, 167-168. [CrossRef] [PubMed]

176. Feuer, A. Protecting New York City, before next time. New York Times. 3 November 2012. Available online: http:/ /www.nytimes.com/2012/11/04/nyregion/protecting-new-york-city-before-next-time.html (accessed on 1 October 2016).

177. Arkema, K.K.; Guannel, G.; Verutes, G.; Wood, S.A.; Guerry, A.; Ruckelshaus, M.; Kareiva, P.; Lacayo, M.; Silver, J.M. Coastal habitats shield people and property from sea-level rise and storms. Nature Clim. Change 2013, 3, 913-918. [CrossRef]

178. Brandon, C.M.; Woodruff, J.D.; Orton, P.M.; Donnelly, J.P. Evidence for elevated coastal vulnerability following large-scale historical oyster bed harvesting. Earth Surf. Proc. Land. 2016, 41, 1136-1143. [CrossRef]

179. Haff, P.K. Neogeomorphology, prediction, and the Anthropic landscape. In Prediction in Geomorphology; Wilcock, P.R., Iverson, R.M., Eds.; Geophysical Monograph Series; American Geophysical Union: Washington, DC, USA, 2003; Volume 135, pp. 15-26.

180. Ma, Z.; Melville, D.S.; Liu, J.; Chen, Y.; Yang, H.; Ren, W.; Zhang, Z.; Piersma, T.; Li, B. Rethinking China's new great wall. Science 2014, 346, 912-914. [CrossRef] [PubMed]

181. Marriner, N.; Morhange, C.; Doumet-Serhal, C.; Carbonel, P. Geoscience rediscovers Phoenicia's buried harbors. Geology 2006, 34, 1-4. [CrossRef]

182. Qingzhou, W. The protection of China's ancient cities from flood damage. Disasters 1989, 13, $193-227$. [CrossRef] [PubMed]

183. Valverde, H.R.; Trembanis, A.C.; Pilkey, O.H. Summary of beach nourishment episodes on the US east coast barrier islands. J. Coast. Res. 1999, 15, 1100-1118.

184. Hapke, C.J.; Kratzmann, M.G.; Himmelstoss, E.A. Geomorphic and human influence on large-scale coastal change. Geomorphology 2013, 199, 160-170. [CrossRef]

185. Willis, C.M.; Griggs, G.B. Reductions in fluvial sediment discharge by coastal dams in California and implications for beach sustainability. J. Geol. 2003, 111, 167-182. [CrossRef]

186. Hinkel, J.; Lincke, D.; Vafeidis, A.T.; Perrette, M.; Nicholls, R.J.; Tol, R.S.; Marzeion, B.; Fettweis, X.; Ionescu, C.; Levermann, A. Coastal flood damage and adaptation costs under 21st century sea-level rise. Proc. Natl. Acad. Sci. USA 2014, 111, 3292-3297. [CrossRef] [PubMed]

187. Dearing, J.A.; Acma, B.; Bub, S.; Chambers, F.M.; Chen, X.; Cooper, J.; Crook, D.; Dong, X.H.; Dotterweich, M.; Edwards, M.E.; et al. Social-ecological systems in the Anthropocene: the need for integrating social and biophysical records at regional scales. Anthropocene Rev. 2015, 2, 220-246. [CrossRef]

188. Walker, B.; Meyers, J.A. Thresholds in ecological and socialecological systems: A developing database. Ecol. Soc. 2004, 3, 1-16.

189. McNamara, D.E.; Werner, B.T. Coupled barrier island-resort model: 2. Tests and predictions along Ocean City and Assateague Island National Seashore, Maryland. J. Geophys. Res. Earth Surf. 2008, 113, F01017. [CrossRef] 
190. Haff, P.K. Technology and human purpose: The problem of solids transport on the Earth's surface. Earth Syst. Dynam. 2012, 3, 149-156. [CrossRef]

191. Haff, P.K. Purpose in the Anthropocene: Dynamical role and physical basis. Anthropocene 2016. [CrossRef]

192. Ellis, E.C.; Antill, E.C.; Kreft, H. All is not loss: plant biodiversity in the Anthropocene. PLoS ONE 2012, 7 , e30535. [CrossRef] [PubMed]

193. Liu, J.; Hull, V.; Batistella, M.; DeFries, R.; Dietz, T.; Fu, F.; Hertel, T.W.; Izaurralde, R.C.; Lambin, E.F.; Li, S.; et al. Framing sustainability in a telecoupled world. Ecol. Soc. 2013, 18, 26. [CrossRef]

194. Rindfuss, R.R.; Walsh, S.J.; Turner, B.L.; Fox, J.; Mishra, V. Developing a science of land change: challenges and methodological issues. Proc. Natl. Acad. Sci. USA 2004, 101, 13976-13981. [CrossRef] [PubMed]

195. Turner, B.L.; Lambin, E.F.; Reenberg, A. The emergence of land change science for global environmental change and sustainability. Proc. Natl. Acad. Sci. USA 2007, 104, 20666-20671. [CrossRef] [PubMed]

196. Parker, D.C.; Hessl, A.; Davis, S.C. Complexity, land-use modeling, and the human dimension: dundamental challenges for mapping unknown outcome spaces. Geoforum 2008, 39, 789-804. [CrossRef]

197. Van Asselen, S.; Verburg, P.H. Land cover change or land-use intensification: simulating land system change with a global-scale land change model. Glob. Change Biol. 2013, 19, 3648-3667. [CrossRef] [PubMed]

(C) 2017 by the author; licensee MDPI, Basel, Switzerland. This article is an open access article distributed under the terms and conditions of the Creative Commons Attribution (CC BY) license (http:/ / creativecommons.org/licenses/by/4.0/). 